\title{
Reading Wilhelm Furtwängler Jurisprudentially: Furtwängler's Music Making in the Light of Legal Philosophy
}

\author{
Rudolf Michael Ondrich ${ }^{1}$
}

\begin{abstract}
This article examines the work of the German conductor Wilhelm Furtwängler through legal philosophy by applying recent scholarship in the intersection of law and music and a method which MacNeil describes as 'reading jurisprudentially.' Furtwängler saw himself as a custodian of a great German cultural tradition, a tradition which included not only German musicians but German jurists such as Friedrich Carl von Savigny and Carl Schmitt. Due to this shared German tradition, concepts in Furtwängler's philosophy of music shares parallels with these German philosophers of law. Furtwängler, much like Savigny, attempted to protect law and music from modern trends which they saw as reducing law and music to a pure philosophical abstraction and in the process severing the organic links between the people and their law and music. Furtwängler also tried to protect music from the Nazis who attempted to have sovereign control over all Germany, including its music. Applying Schmitt's idea of sovereignty as 'he who decides on the exception' to Furtwängler's 1942 performance of Beethoven's Ninth Symphony in Berlin, Germany, I will argue that Furtwängler protects the love and humanism of the music by suspending it and by doing so preventing it from being associated with Nazism.
\end{abstract}

Keywords Furtwängler · Savigny $\cdot$ Schmitt $\cdot$ Agamben $\cdot$ Beethoven · Law and music · Jurisprudence · German · Hitler · NAZI

Rudolf Michael Ondrich

rudolf.ondrich@griffithuni.edu.au

1 Graduate of the Griffith Law School, Griffith University, Brisbane, Australia 


\section{Introduction}

The German conductor and composer Wilhelm Furtwängler (1886-1954) represents a unique place in Western classical music. He is recognised as being, if not one of the greatest, the greatest conductor to have ever lived, 'a musical genius. ${ }^{1}$ His deeply felt performances of composers such as Ludwig van Beethoven, Johannes Brahms and Anton Bruckner have left a lasting and formidable impression and are celebrated even today, decades after his death in 1954. The Greek soprano Maria Callas, after discussing various conductors and their interpretative approaches to Beethoven's Eighth Symphony, exclaimed that 'to me, he was Beethoven.' ${ }^{2}$ The musicologist Walter Frisch, after analysing several performances given by various conductors of Brahms' symphonies, expressed the view that he is 'the finest Brahms conductor of his generation, perhaps of all time. ${ }^{3}$ Various active and lively Furtwängler societies in countries such as France and Japan $^{5}$ devote their efforts in celebrating and promoting his work. There is no doubt as to Furtwängler's lasting legacy and significance in western music.

Furtwängler held the post of principal conductor of the Berlin Philharmonic Orchestra between 1922 and 1945, and again from 1952 until his death in 1954. During this time he oversaw many trials and tribulations in German life, from the fledgling Weimar Republic, to the rise and fall of the Third Reich, and the creation of a post-war Germany. Despite other prominent European conductors such as Arturo Toscanini (from Italy) and Bruno Walter (from Germany) leaving in the 1930s in protest at the rise of fascist governments across the continent, Furtwängler decided to stay and work in Germany. After the war he was accused of aiding the Nazi cause and was tried in a denazification tribunal where he was acquitted of all charges in 1946. He resumed his conducting career and died in 1954. ${ }^{6}$ Despite his acquittal, a cloud remains over his head with some today questioning why he decided to stay and work in Germany during the Nazi years and, despite not being a Nazi himself, the amount of prestige he leant to the regime by staying in Germany. ${ }^{7}$

Much ink has been spilt over this great man of music. Various biographies and musical analysis of his performances have been done. It would be difficult to add something new to this scholarship if I were to merely do another biographical or musicology work. This article therefore is not primarily an exercise in musicology, even though musical concepts permeate it throughout. Rather it is about law, specifically jurisprudence. I will attempt to read and analyse Furtwängler's work as a jurisprudential text. How can legal theory be used to analyse Furtwängler's work?

\footnotetext{
1 Hans-Hubert Schönzeler, Furtwängler (Duckworth, 1990) 123.

2 John Ardoin, The Furtwängler Record (Amadeus Press, 1994) 12.

3 Walter Frisch, Brahms: The Four Symphonies (Schirmer Books, 1996) 183.

4 Société Wilhelm Furtwängler http://www.furtwangler.org/.

5 The Wilhelm Furtwängler Centre of Japan http://furt-centre.com/english/eindex.htm; Furtwaengler Institute Tokyo http://www.kt.rim.or.jp/ otakesan/furt.htm.

6 Sam Shirakawa, The Devil's Music Master: The Controversial Life and Career of Wilhelm Furtwängler (Oxford University Press, 1992).

7 Ibid 364.
} 
How does Furtwängler's work comment on and extend our understanding of jurisprudential matters? And moving more broadly, what does this reveal about the relationship between law and music?

I will analyse Furtwängler as a figure of jurisprudence, particularly that of a sovereign power. Furtwängler saw himself as a custodian of a great German tradition, a tradition which included not only German musicians but German jurists such as Friedrich Carl von Savigny. Furtwängler, much like Savigny, attempted to protect law and music from modern trends which they saw as reducing law and music to a pure philosophical abstraction and in the process severing the organic links between the people and their law and music. Furtwängler also tried to protect music from the Nazis who attempted to have sovereign control over all Germany, including its music. Applying Carl Schmitt's idea of sovereignty as 'he who decides on the exception' ${ }^{8}$ and to suspend the operation of the law to Furtwängler's 1942 performance of Beethoven's Ninth Symphony in Berlin, Germany, I will argue that Furtwängler protects the love and humanism of the music by suspending it and by doing so preventing it from being associated with Nazism.

This analysis of Furtwängler's work through the lens of legal philosophy reveals many paradoxes in his work. On the one hand he was a cultural conservative, deeply committed to both German musical tradition and culture more generally. He declared himself to be 'a German artist, that is, a representative of the Germany that manifests itself in German music' ${ }^{9}$ and attacked those who wished to unshackle music from tonality for their desire 'with progress, with being original at all costs. ${ }^{10}$ On the other hand, he protects music from Nazism by being radically inventive, namely by crafting a blazingly intense and violent interpretation of Beethoven's Ninth Symphony, an interpretation far removed from more traditional views of the symphony as representing love, hope and unity. Furtwängler appears to be a politically aloof character. He declared that 'music and politics have nothing to do with each other, ${ }^{11}$ and yet his music making itself is deeply political and cannot be analysed without an acute awareness of the political situation around him at the time. Finally, Furtwängler fulfils the music, in this case Beethoven's Ninth Symphony, by suspending its ordinary meaning, namely that of love, hope, unity etc. so that these concepts can be fulfilled with genuine conviction in his post-war performances of the symphony.

Reading Furtwängler's work through a jurisprudential lens will have several effects. In a general sense, it will show that 'non-legal' areas such as music are in fact deeply imbued with jurisprudential matters. Music is not mere sound for entertainment value but can carry and express deep jurisprudential topics. Acting in a jurisprudential manner is not limited to lawyers, judges and other 'legal' actors,

\footnotetext{
${ }^{8}$ Carl Schmitt, Political Theology: Four Chapters on the Concept of Sovereignty (George Schwab trans, University of Chicago Press, 2005) 5 [trans of: Politische Theologie: Vier Kapitel zur Lehre von der Souveränität (2nd ed, 1934)].

9 Wilhelm Furtwängler, Notebooks 1924-1954 (Shaun Whiteside trans, Quartet Books, 1989) 145.

10 Wilhelm Furtwängler, Furtwängler on Music (Ronald Taylor ed and trans, Scolar Press, 1991) 133-134.

11 Shirakawa, above n 6, 203.
} 
but can be seen in the actions of those seen to be 'far' and distant from law, in this case musicians. Perhaps then our distinctions between 'legal' and 'non-legal' are not as clear cut as it may be on first impressions. Specifically pertaining to Furtwängler, it will show that his musical response to the conditions of Nazi Germany is itself imbued with jurisprudence and cannot be properly understood without reference to both the political and legal situation of the time. Furtwängler responded to an extreme legal and jurisprudential situation, namely the Nazi regime, by engaging in jurisprudence himself. Unlike more traditional means of expressing jurisprudence (via written books, articles, case law etc.) Furtwängler expressed (or coded) his jurisprudence through the music itself.

This article is divided into five parts. After an introductory first part (this part), the second part gives an overview of current law and music scholarship and examines the ways in which this article interacts with and extends upon this preexisting scholarship. The third part is an overview of Furtwängler's written philosophy of music and how it relates to German philosophy of law, in particular the work of Savigny and Schmitt, and in so doing demonstrating that Furtwängler's philosophy of music emanates and springs out of general German philosophical trends. Due to this shared German tradition, concepts in Furtwängler's philosophy of music shares parallels with these German philosophers of law. Part four moves away from analysing Furtwängler's written philosophy of music to his actual music making, namely a performance given by Furtwängler of Beethoven's Ninth Symphony in Berlin, 1942, and in doing so examines how Furtwängler attempted to protect German music from the Nazis by reference to Carl Schmitt's idea of sovereignty. Furtwängler suspends the ordinary interpretation of the Ninth Symphony of love, hope, unity etc. by crafting a most violent and intense interpretation of the work, and in doing so attempts to protect this ordinary interpretation from being associated with Nazism. It shows that while he was deeply committed to tradition, he was radically inventive in order to protect that tradition. Part five gives a general conclusion to the whole article.

\section{How This Article Fits into and Extends Current Law and Music Scholarship}

It is beyond the scope of this article to furnish a detailed review of current law and music scholarship. Those interested in such an exercise are directed to the work of Manderson ${ }^{12}$ and Parker. ${ }^{13}$ It is pertinent however at this stage to situate this article within pre-existing law and music scholarship for two main reasons-first to illumine this (relatively) unknown area of scholarship to those who have not come across it before, and second to show how this article engages with and expands this area of scholarship.

\footnotetext{
12 Desmond Manderson, 'Towards Law and Music: Sara Ramshaw, Justice as Improvisation: The Law of the Extempore (Oxford: Routledge, 2013)' (2014) 25 Law and Critique 311.

13 James E Parker, Acoustic Jurisprudence: Listening to the Trial of Simon Bikindi (Oxford University Press, 2015) ch 1.
} 
This works attempts to further law and music scholarship in two ways. The first one is the substantive topic of study, namely focusing on the work of Furtwängler. It is somewhat surprising that, despite this emerging scholarship in law and music which so far has focused on rock music, ${ }^{14}$ jazz musicians ${ }^{15}$ and classical music in general $^{16}$ nothing to date has been written about Furtwängler from the perspective of law and music scholarship. There are several reasons why Furtwängler's work is worthy of study through a legal lens. He is a towering figure in classical music and considered to be, if not one of the greatest conductors, the greatest conductor to have ever lived. In addition, his presence and activity in Germany during the Nazi era provides fertile ground for analysis through a jurisprudential lens due to the extreme legal and political situation there at the time. Not only are there numerous recordings available of Furtwängler conducting music but he also expressed a rather detailed philosophy of music which is also capable of being analysed using legal philosophy. While predominately dealing with issues pertaining to music, Furtwängler's philosophy was broader than that. His 'philosophy of music was a philosophy of life.' ${ }^{17}$ He saw music as more than just mere sound, but as a moral force ${ }^{18}$ music having the power to 'ennoble the soul, enhances the sensitivity of mind and emotional consciousness, and serves the holistic education of man's emotional, mental and spiritual faculties. ${ }^{19}$ Furtwängler saw himself as part of the great German intellectual tradition, ${ }^{20}$ the same tradition which produced not only great German musicians such as Beethoven, Brahms and Bruckner but also notable German jurists such as the nineteenth century Friedrich Carl von Savigny (1779-1861) and Furtwängler's rough contemporary Carl Schmitt (1888-1985). These thinkers spring from a common German intellectual foundation and tradition, and thus similar concepts in Furtwängler's philosophy of music are also able to be found in the work of Germany's great philosophers of law. To the best of my knowledge, no previous piece of law and music scholarship has attempted to analyse at length an artist's written philosophy of music through legal philosophy. In this sense then, I will attempt to show that both music itself (as represented by a

\footnotetext{
${ }^{14}$ See for example: Robbie Sykes and Kieran Tranter, "You gotta roll/rule with it': Oasis and the concept of law' (2015) 24 Griffith Law Review 571; Robbie Sykes and Kieran Tranter, 'A Just (Electric Lady) Land: Jimi Hendrix and John Rawls' (2017) 29 Law \& Literature 383.

15 See for example: Sara Ramshaw, Justice as Improvisation: The Law of the Extempore (Routledge, 2013).

16 See for example: Desmond Manderson, Songs Without Music: Aesthetic Dimensions of Law and Justice (University of California Press, 2000); James Burrows Thomas, Curious Connections: Master Musicians and the Law (Supreme Court of Queensland Library, 2006); and the law and music special edition of the Cardozo Law Review, namely: Desmond Manderson and David Caudill, 'Modes of Law: Musical and Legal Theory-An Interdisciplinary Workshop Introduction' (1999) 20 Cardozo Law Review 1325; and subsequent articles.

17 Ronald Taylor, 'Introduction' in Wilhelm Furtwängler, Furtwängler on Music (Ronald Taylor ed and trans, Scolar Press, 1991) vii, xi.

18 James Martin Clark, Celebrating Music: Wilhelm Furtwängler, Edwin Fischer, Wilhelm Kempff and the German Romantic Performance Tradition (PhD Thesis, University of Connecticut, 2005) 49.

19 Taylor, above n 17, xi.

${ }^{20}$ Furtwängler, above n 9, 148, 159.
} 
recording) $)^{21}$ as well as music philosophy can be analysed along side legal philosophy.

The second way in which this work extends law and music scholarship is a methodological one. While it is ultimately in law, I will attempt to make the music an integral and vital aspect of the argument itself and not a mere 'add on.' The historian Erik Levi notes that little scholarship has been done analysing the interaction of musical and political life in the Nazi era due to the

very abstract nature of music as an art form. This poses special difficulties for any historian who seeks to draw unambiguous parallels between music and political ideology, difficulties which appear, at least on the surface, to be far less problematical in the visual arts or films. ${ }^{22}$

This difficulty is also shared with law and music scholarship, and which may help explain why there is also so little written in the field. Furthermore, of the law and music scholarship which does exist, a lot of it only deals with music by way of metaphor or simile and does not make music an integral part of the argument. Desmond Manderson's references to music in his book Songs Without Music: Aesthetic Dimensions of Law and Justice, ${ }^{23}$ as James Parker rightly notes, is merely that of a metaphor to help illuminate an aesthetic dimension in law, but does not engage with how music itself can be a potential source of law or analysis/criticism of the law and/or jurisprudential issues. ${ }^{24}$ A good example of this is the chapter Requiem: Green Death-Aesthetic Interpretations and Influences in the Death Penalty. ${ }^{25}$ Using Mozart's Requiem Mass as an analogy, Manderson attempts to 'explore the failure of reason to effectively control the legal system' ${ }^{\text {, }}$ through death penalty cases in the United States, arguing that decisions based on the death penalty are driven by non-rational considerations such as emotion. This central argument however would have in my view the exact same intellectual force had all the references to Mozart's Requiem been excised from the text. References to the Requiem are at best a simile, and do not in any major way drive the fundamental argument being made. Similarly, while Ramshaw in her book Justice as

\footnotetext{
${ }^{21}$ It is debatable however if whether or not an audio recording of a performance is in fact 'music.' For Sergiu Celibidache, a pupil of Furtwängler, 'a recording will never be music and will never replace the real, live experience.' [Ludwig van Beethoven: Symphony No. 9 in D minor op. 125 'Choral,' Helen Donath soprano, Doris Soffel mezzo-soprano, Siegfried Jerusalem tenor, Peter Lika bass, Munich Philharmonic Orchestra, conducted by Sergiu Celibidache, Recorded 17 March 1989 (EMI Compact Disc, Catalogue Number 7243556842 6, 1999) Liner Notes 26]. For Celibidache and those who share his opinion, presumably then this article does not contribute to law and music scholarship as there is no actual music being analysed in the article itself. Defining what exactly 'music' constitutes, while being a deeply fascinating debate in of itself, is beyond the scope of this article. For sake of argument however I will sidestep this vexed question and will treat audio recordings of Furtwängler conducting as constituting music.

22 Erik Levi, Music in the Third Reich (Macmillan, 1994) xi.

23 Manderson, above n 16.

24 Parker, above n 13, 31.

25 Manderson, above n 16, 93-129.

26 Ibid 94.
} 
Improvisation: The Law of the Extempore ${ }^{27}$ engages in thorough analysis of jazz music, her ultimate claim is that law and justice are 'fundamentally improvisational,' which, as James Parker notes, 'is not, however, to say acoustic. ${ }^{28}$ In other words there is no claim being made that there is a necessary link between law and justice to music itself, but rather improvisation in jazz music is used as an analogy to show improvisation in law and justice.

One way to make the music an integral part of the arguments is to make use of a methodology devised by William MacNeil, namely his idea of 'reading jurisprudentially. ${ }^{29}$ The aim of the methodology is to look at how 'concepts of law [jurisprudence] [are]... reflected in, but also refracted by literary [and other] texts' 30 and in doing so examine how those working in 'non-legal' areas (e.g. popular culture, novelists, film makers etc.) examine and comment upon legal theory. ${ }^{31}$ MacNeil describes this methodology as having three steps. The first step is to find subtextual analogies between the cultural text and a legal theory by 'identify[ing] patterns... between the literary [or other text] and the legal text, ${ }^{32}$ for example a turn of phrase or a motif. The second step is to associate these patterns in the literary text expressly with a legal theory, for example stating that a character is an 'embodiment of [legal] positivism,' and so forth. ${ }^{33}$ The third and final step is to explore 'the extent to which these novels' subtextual analogies reinterpret, indeed signify jurisprudence, generating a new intertext of the legal and the literary that, potentially, reimagines the juridical imagery. ${ }^{34}$ MacNeil himself uses this methodology to analyse various films ${ }^{35}$ and novels. ${ }^{36}$ More recently, Robbie Sykes and Kieran Tranter have demonstrated that this method of 'reading jurisprudentially' can also be used to analyse music, in particular the rock band Oasis, ${ }^{37}$ as figures of jurisprudence. 'Reading jurisprudentially' then is a broad methodology which is able to be used to analyse a plethora of what would be considered to be 'non-legal' disciplines such as films, novels and music, through the lens of jurisprudence. This methodology too has the effect of making the 'non-legal' aspect of analysis integral to the argument itself, and not some mere analogy. It is integral in the sense that, unlike Manderson who uses music as a metaphor, the arguments made by Sykes and Tranter collapse if discussion of the music itself is stripped away. Analysing how Oasis' work relates to and comments upon Heart's theory of legal positivism for example cannot be done if discussion of Oasis' work is stripped

\footnotetext{
27 Ramshaw, above n 15.

${ }^{28}$ Parker, above n 13, 31 .

29 William MacNeil, Lex Populi: The Jurisprudence of Popular Culture (Stanford University Press, 2007) 156.

30 William MacNeil, Novel Judgments: Legal Theory as Fiction (Routledge, 2012) 4.

31 MacNeil, above n 29. 157.

32 MacNeil, above n 30, 14.

33 Ibid.

34 Ibid 15.

35 MacNeil, above n 29, 44-60, Ibid 97-115, Ibid 116-131.

36 MacNeil, above n 30.

37 Sykes \& Kieran, above n 14.
} 
away from the argument. This article will attempt to build on that methodology by making the music itself a vital, and not merely incidental, aspect of the argument.

In addition, giving a sustained analysis of the work of one seminal musician, in this case Furtwängler, helps to avoid giving an argument that Edward Mussawir describes as being 'too metaphysical, too detached from material and local encounters, ${ }^{38}$ but instead it becomes 'the subject of a more material and local encounter.' ${ }^{39}$ Manderson's work in particular gives the impression that the nature of the musical works he discusses (e.g. Mozart's Requiem) are eternal and unchanging in their meaning. In doing so he gives relatively scant discussion of how actual individual musicians relate themselves to the music itself, let alone how a musician may over time develop a differing perspective on the work. He briefly considers the great Canadian pianist Glenn Gould's 'idiosyncratic rendering' ${ }^{40}$ of Johann Sebastian Bach's Well-Tempered Clavier but then urges us to 'move away from the specifics of a particular, to a consideration of the musical text.' ${ }^{41}$ In contrast, giving a sustained analysis of one musician avoids the potential trap of attempting to give a grand narrative as to the absolute nature of music generally and of particular musical works, a task that is well-nigh impossible, to a more local analysis of one master musician's particular encounter and their relationship with the music itself. If we are to study law and music together, we should not ignore what individual 'masters' of music do and in doing so avoid the trap of treating music in a general, and almost generic, sense.

\section{General Introduction to Furtwängler's Philosophy of Music and Its Relation to German Philosophy of Law_Friedrich Carl von Savigny and Carl Schmitt}

Why should those studying legal philosophy take an interest in Furtwängler's philosophy of music? On the surface at least, both areas of philosophy are rather disparate from each other. Music philosophy deals with music and legal philosophy deals with law. What then can a musician's philosophy of music reveal about the philosophy of law? One strong idea I wish to draw out from analysing Furtwängler's philosophy of music is to show that even music itself can be imbued with juridical concepts, concepts such as the ultimate source of law/music, its purpose, and its relation to the community at large. Furthermore, it will highlight that ultimately both (and in particular German) music and law spring out and come from a common intellectual tradition. While predominately dealing with issues pertaining to music,

\footnotetext{
38 Nick Piška, 'Review: Edward Mussawir, Jurisdiction in Deleuze, The Expression and Representation of Law' (2013) 76 The Modern Law Review 184, 184.

39 Edward Mussawir, Jurisdiction in Deleuze: The Expression and Representation of Law (Routledge, 2011) xii.

${ }^{40}$ Manderson, above n 16, 4.

41 Ibid.
} 
Furtwängler's philosophy was broader than that. His 'philosophy of music was a philosophy of life. ${ }^{42}$ He saw music as more than just mere sound, but as a moral force, ${ }^{43}$ music having the power to "ennoble the soul, enhances the sensitivity of mind and emotional consciousness, and serves the holistic education of man's emotional, mental and spiritual faculties. ${ }^{44}$ Furtwängler saw himself as part of the great German intellectual tradition, ${ }^{45}$ the same tradition which produced not only great German musicians such as Beethoven, Brahms and Bruckner but also notable German jurists such as the nineteenth century Friedrich Carl von Savigny (1779-1861) and Furtwängler's rough contemporary Carl Schmitt (1888-1985). As these thinkers' spring from a common German intellectual foundation and tradition, similar concepts in Furtwängler's philosophy of music are also able to be found in the work of Germany's great philosophers of law. What thematically links these three thinkers-Furtwängler, Savigny and Schmitt-is their desire for protection, either protection of an aesthetic of law and music, or their protection against political forces (namely Nazism) which they saw as being detrimental to the law and music. Their work cannot be properly understood without this idea of custodianship and protection of German culture in mind.

This idea of custodianship of a great German musical and legal tradition stems in part from these three scholars being concerned with not what they saw as narrow debates in both law and music but for more fundamental issues. As Mussawir notes, Schmitt and Savigny were 'on the one hand, certainly partisan but also deeply ambivalent in relation to the narrow ideological battle lines of their eras ${ }^{46}$ such as the debate between natural and positive law for instance, ${ }^{47}$ but 'on the other, retaining a broader and enduring intellectual relevance, ${ }^{48}$ by focusing on what they saw as more fundamental issues, to 'renewed attention to a much older problem of history and jurisprudence.' 49 This is also shared by Furtwängler, who was concerned with more fundamental issues within music. One example of this is the whole debate regarding performance practice (those who advocate for a 'purposeful' or 'spiritual' interpretation of the music compared to those who advocate a more 'literal' or 'strict' interpretation). For Furtwängler, this debate can be rendered superfluous if 'a [musical] work is not regarded as a stockpile of romantic 'moods'... or as an arid mechanical exercise in abstract forms... but as an unfolding organism, a process of vital, organic development ${ }^{50}$ which leads to 'one [interpretive] approach, only one manner of performance, that is appropriate,

\footnotetext{
42 Taylor, above n 17, xi.

43 Clark, above n 18, 49.

44 Taylor, above n 17, xi.

45 Furtwängler, above n 9, 148, 159.

46 Edward Mussawir, 'The Graves of Law: The Work of Jurisprudence in Bachofen's Study of Tombs' (2015) 171 Telos 131, 134.

47 Ibid 132.

48 Ibid 134.

49 Ibid 132

${ }^{50}$ Furtwängler, above 10, 13-14.
} 
inherently 'correct'. ${ }^{51}$ This focus then on more fundamental issues within law and music influences the work of all three scholars.

Furtwängler not only practiced the art of music itself by conducting and composing, but he also left a detailed and substantial body of written work outlining his philosophy of music. Furtwängler seemed reluctant to even write on this topic, much preferring as a musician to express himself exclusively through the music itself. As early as 1915 he wrote that it is not normally the business of an artist to make general observations in philosophical terms' ${ }^{52}$ and that 'I would have given a great deal to be spared this effort, ${ }^{53}$ but

the reason I cannot avoid doing so lies with the contemporary situation, which unhappily demands from all artists a degree of awareness and certainty about the nature of art which was not necessary in earlier and happier times. Given the incredible ideological confusion that prevails today, an awareness of the situation can offer the artist a measure of reassurance and help him preserve his integrity in the face of an over-intellectualized environment. ${ }^{54}$

Roughly a century before Furtwängler, Savigny was equally distraught as to what he saw was a crisis in law. Schmitt notes that Savigny's famous 1814 text $O f$ The Vocation of Our Age for Legislation and Jurisprudence ${ }^{55}$ 'was an existential selfreflection on jurisprudence... a great call to jurisprudence to be more than the guardian of state law. ${ }^{56}$ Savigny's ultimate aim was 'to rescue the dignity of a legal estate. ${ }^{57}$ What exactly then are these crises in the nature of music and law that Furtwängler and Savigny are responding to?

Both Furtwängler and Savigny were concerned that recent developments in both law and music were in effect severing this organic connection between the people and their music and law. What replaced this organic connection to music and law was instead the creation of music and law based on abstract theoretical notions. As Mussawir observes, Savigny took aim at legal philosophers who wanted to 'reduce matters of law to a pure philosophical abstraction. ${ }^{58}$ Savigny found himself on the opposite side of a debate, headed by fellow German jurist Anton Friedrich Justus Thibaut (1772-1840), who called for the codification of German law in a similar

\footnotetext{
51 Ibid 14.

52 Ibid 123.

53 Ibid.

54 Ibid.

55 Frederick Charles von Savigny, Of The Vocation of Our Age for Legislation and Jurisprudence (Abraham Hayward trans, Lawbook Exchange, 2011) [trans of: Vom Beruf unserer Zeit für Gesetzgebung und Rechtswissenschaft (2nd ed, 1831)].

56 Carl Schmitt, 'The Plight of European Jurisprudence' (G.L Ulmen trans) (1990) 83 Telos 35, 56 [trans of: Die Lage der europäischen Rechtswissenschaft (2nd ed, 1973)].

57 Ibid.

58 Mussawir, above n 46, 134.
} 
way that French law was at the time, with the ultimate aim of providing political unity. ${ }^{59}$ Savigny based his opposition to legal codification

from the perspective of one of the most sensitive and astute historians and aestheticians of law in his time. What he could not stand to endure was the destruction, at the hands of an impetuous modern rationality, of much of the most finely crafted and time-moulded artefacts of juridical thought. ${ }^{60}$

Similarly, Furtwängler lamented the fact that 'musical life today is characterised by a massive increase in theorising and a corresponding decline in practical music making. ${ }^{, 61}$ Specifically, for Furtwängler this impetuous modern rationality lead to a concept called atonality - a system of composition developed by the Austrian composer Arnold Schönberg which does not require the use of a cadence, which is the basis of tonality ${ }^{62}$ - which Furtwängler lamented has created 'two kinds of music today-one that is reviewed in journals, and one that is actually played. ${ }^{63}$

It is clear that the deep-rooted, if unspoken mutual confidence which existed between composer and public in the nineteenth century, despite many conflicts and differences of opinion, have been shaken. Little is left of that feeling of being joined together with the public through a bond of spiritual unity, of trusting the public and serving it... The modern composer now confronts his listeners with a set of demands; no longer does he subordinate himself to their wishes but expects them to submit to his authority. He has ceased being part of the community and is now above it. ${ }^{64}$

For Furtwängler, the use of atonality signalled

for the first time [that] the substance itself, the stuff of which music is made, the sound and harmonies of which it is composed, became the starting-point and not as in the past, man, who changes with the course of history and makes use of the substance, impressing his stamp upon it. ${ }^{65}$

Similarly, for Savigny, he felt that those who were advocating for a code were 'reduc[ing] matters of law to a pure philosophical abstraction' 66 and in doing so severing the organic links between the people and its law.

To avoid the separation of law and music from the people, both theorists stressed the important links between law and music with the community at large. Law and music are not some abstract entities, rather there is an organic connection between people and its law and music. Furtwängler expressed the view that

\footnotetext{
59 Reindhard Zimmermann, 'Characteristic Aspects of German Legal Culture' in Mathias Reinmann \& Joachim Zekoll (eds), Introduction to German Law (Klewer Law International, 2nd ed, 2005) 1, 4.

${ }^{60}$ Mussawir, above n 46, 134.

61 Furtwängler, above n 10, 140.

62 Wilhelm Furtwängler, Concerning Music (L J Lawrence trans, Boosey \& Hawkes, 1953) 82.

63 Furtwängler, above n 10, 140.

64 Ibid 144.

65 Furtwängler, above n 62, 81 .

66 Mussawir, above n 46, 134.
} 
From the time of Bach this public was a kind of 'supreme court' for composers, the body that upheld certain principles and standards. When theoreticians and critics talk today of the 'rules' of music that they have derived from Bach, Beethoven, Schubert, Wagner, Brahms etc., we must realise that these rules are inconceivable without the existence of a public. ${ }^{67}$

The reason for this is that the system of tonality itself came organically from the people.

[Tonal music] embraces the whole fullness of organic life and reflects a vast world of independent forms - the song, the fugue, the sonata are but fundamental types. It can do all this because it is self-sufficient. It is in deep accord with the biological construction of human nature. ${ }^{68} \ldots$ It contains the problem of tension and relaxation. All organic life existing in time - and music is an art which has its being in time - is subject to the alternation between tension and relaxation. This fluctuation between these two, tension and relaxation, represents the rhythm of life; there is not a moment as long as we breathe, in which one or other does not prevail. Both are organically connected. ${ }^{69}$... Tonality appears to us in all respects to be a law of nature, howbeit a law of nature which 'holds sway' within the human soul and its emotions. $^{70}$

Tonality 'developed unceasingly and according to its own laws-as with every true natural process' ${ }^{71}$ and is 'a system of separate forces running their course independently of our intentions or wishes. 72

This language bears "striking similarity and underlying unity ${ }^{73}$ with Savigny's view of the law. For Savigny, there is an 'organic connection of law with the being and character of the people. ${ }^{74}$ The law emanates and develops from the Volksgeist, or the spirit of the people. This Volksgeist is 'linked to the biological heritage of a people. ${ }^{75}$ As such, the law cannot be traced to 'arbitrary origin ${ }^{, 76}$ or intentional conscious will.

\footnotetext{
${ }^{67}$ Furtwängler, above n 10, 143-144.

68 Furtwängler, above n 62, 86.

69 Ibid 87.

70 Ibid 93.

71 Ibid 83.

72 Ibid 84.

73 To borrow a phrase from the High Court of Australia case of Pfennig $v$ The Queen (1995) 182 CLR 461, 484; where Mason CJ, Deane and Dawson JJ held that, in a criminal trial, 'striking similarity, underlying unity and other like descriptions of similar facts are not essential to the admission of [similar fact] evidence, though usually the evidence will lack the requisite probative force if the evidence does not possess such characteristics.'.

74 Savigny, above n 55, 27.

75 Michael Freeman, Lloyd's Introduction to Jurisprudence (Sweet \& Maxwell, 9th ed, 2014) 913.

76 Savigny, above n 55, 24.
} 
In the general consciousness of a people lives positive law and hence we have to call it people's law (Volksrecht). It is by no means to be thought that it was the particular members of the people by whose arbitrary will, law was brought forth... Rather it is the spirit of a people living and working in common in all individuals, which gives birth to positive law, which therefore is to the consciousness of each individual not accidentally but necessarily one and the same. $^{77}$

It is worth noting in passing that this idea of 'organicness' is not limited to German music and legal philosophers. The German philosopher of history Oswald Spengler (1880-1936) thought of culture as being an organic conception. ${ }^{78}$ Despite the Nazis attempted to present Spengler's work as part of Nazi cultural tradition, he 'thought National Socialism was a catastrophe. ${ }^{79}$

Ultimately Furtwängler and Savigny hoped that their views on music and law would help create and protect unity in Germany. In an open letter written to Goebbels in where Furtwängler decries efforts to prevent Jewish musicians such as Bruno Walter and Otto Klemperer from conducting, Furtwängler claims that it is the function of art and artists to unite, not to divide. ${ }^{80}$ Similarly, Savigny hoped that a jurisprudence which recognised the organic connection between the people and its law 'would promote... a spirit of unity among Germans.' 81

While both Furtwängler and Savigny's respective philosophies share an affinity with each other this is less obvious than when one compares the work of Furtwängler with that of Carl Schmitt. Their basic temperaments are in themselves in seeming contrast with each other. Both Furtwängler and Savigny were romantics, with philosophies heavily influenced by nineteenth century Germanic romanticism. ${ }^{82}$ This difference between Savigny and Furtwängler when compared to Schmitt can be seen even in their respective linguistic and writing styles. Savigny's and Furtwängler's written works are steeped in traditional Germanic modes of expression. Abraham Hayward, in his English translator's preface to $O f$ The Vocation of Our Age for Legislation and Jurisprudence ${ }^{83}$ notes the particular difficulties in translating the work from German to English. 'Now Savigny's style is very highly esteemed by his countrymen... but his modes of thought and expression differ so very widely from those in fashion amongst [English speaking people]. ${ }^{84}$ Similarly, Ronald Taylor in the preface of his set of translations of various

\footnotetext{
77 Friedrich Carl von Savigny, System of The Modern Roman Law (William Holloway trans, J Higginbotham, 1867) vol 1, 12.

78 Oswald Spengler, The Decline of The West (Charles Francis Atkinson trans, George Allen \& Unwin, 1932) [trans of: Der Untergang des Abendlandes (first published 1932)].

79 Michael Tanner, footnote p 98 in Furtwängler, above n 9.

80 Furtwängler, above n 10, 138.

81 Savigny, above n 55, back cover blurb.

82 Freeman, above n 75, 913; Michael Tanner, “Introduction' in Furtwängler n 9, i.

83 Savigny, n 55.

84 Abraham Hayward, 'Translator's Preface' in Savigny, ibid vii.
} 
Furtwängler essays, notes that 'his style-intensely German, sometimes excruciatingly so-can be convoluted and unwieldly.' 85 Michael Tanner states that Furtwängler's essays and notes 'are written in a style which is often torturous, abstruse and convoluted' ${ }^{86}$ due to his 'education, mainly conducted privately, ${ }^{87}$ which 'was in the German tradition of philosophising as it was practiced by Kant, Hegel, and Schopenhauer among other giants of the late classical and early romantic periods. ${ }^{88}$ This romantic style of writing sharply contrasts to that of Carl Schmitt's modern, clear style. Ellen Kennedy, in her translator's note for her translation of The Crisis of Parliamentary Democracy, ${ }^{89}$ expresses the view that 'Schmitt's writing style is remarkably clear and free of the convulsions that often burden academic German. ${ }^{90}$ George Schwab in his translator's notes for his English translation of The Concept of The Political also notes that 'as a rule Schmitt's style does not suffer from the usual problems one encounters in what is generally known as 'professorial German'. ${ }^{91}$ Clearly then, Schmitt was, at least in terms of linguistic style, firmly rooted in the modern currents of his day and age, which cannot be said of Furtwängler.

This split between the romanticism of Savigny and Furtwängler and the modernism of Schmitt is also born out in the substance of their respective philosophies. On the surface at least, Furtwängler's philosophy of music appears to be antithetical to Schmitt's philosophies of law and politics. Furtwängler saw the ultimate basis of music as being love, proclaiming that 'the artist is the man of love'92 and that 'art does not express a nation's hate, but its love. ${ }^{93}$ In contrast to this, Schmitt famously saw political life as predicated on an antagonistic relationship between that of 'friend and enemy." 94

The [enemy] is ... the other, the stranger; and it is sufficient for his nature that he is, in a specially intense way, existentially something different and alien, so that in the extreme case conflicts with him are possible. ${ }^{95}$

Without this friend/enemy distinction, 'political life would vanish altogether.' 96 Similarly, Schmitt saw the foundation of legal order constituting a sovereign power

\footnotetext{
85 Taylor, above n 17, xvi.

86 Michael Tanner, “Introduction' in Furtwängler n 9, i.

87 Ibid.

88 Ibid.

89 Carl Schmitt, The Crisis of Parliamentary Democracy (Ellen Kennedy trans, MIT Press, 1985) 35 [trans of: Die geistesgeschichtliche Lage des heutigen Parlamentarismus (first published 1923)].

90 Ellen Kennedy, 'A Note on the Text and Translation' in Schmitt, ibid ix.

91 Carl Schmitt, The Concept of The Political: Expanded Edition (George Schwab trans, University of Chicago Press, 2007) 17 [trans of: Der Begriff des Politischen (2nd ed, 1932)].

92 Furtwängler, above 56, 74.

93 Ibid 57.

94 Schmitt, above n 94, 26.

95 Ibid 27.

96 Ibid 51.
} 
which had the ability to suspend the ordinary law and in turn the rights that the law provides to the people. ${ }^{97}$

I would suggest however that what links Furtwängler and Schmitt together is their ultimate concern for protection with both wanting to preserve and protect a great cultural tradition which they saw as being under attack. Schmitt's original intention of devising the friend/enemy distinction was to help protect the weak Weimar state from threats against it—namely left wing communists and right wing fascists, which included Nazism. ${ }^{98}$ Similarly, Schmitt's ultimate aim for his theory of sovereignty was to give the sovereign an effective tool to protect the polity with. ${ }^{99}$ Schmitt wanted to give more power to the then-President Paul von Hindenburg and was dismayed at the President's reluctance to issue decrees, which in his view enabled 'even negatively inclined parties to operate and compete for power. ${ }^{100}$

Ultimately Schmitt's aim at protecting the Weimar state from radical forces failed. Recognising this failure, in 1943 and 1944 he travels to various European cities to deliver a lecture entitled The Plight of European Jurisprudence. ${ }^{101}$ For Mussawir, this lecture represents 'a shift in emphasis,'102 'one finds no trace of Schmitt's signature tendency to theologize the grounds of law in relation to a kind of existential political urgency.' ${ }^{103}$ In addition, the belligerent language found in concepts such as the friend/enemy distinction are absent from his lecture. On this level it is certainly true that Schmitt's lecture does indeed departs from his previous scholarship. But on another level there is a sense of continuity, specifically in Schmitt's ultimate aim in his scholarship, namely that of protection. While Schmitt in this lecture reneges on his previous enthusiastic support of rule by decree, he does so on the need to protect the integrity of law which he felt was under threat from what he called the 'motorisation' of legislation. ${ }^{104}$ Schmitt wanted to protect jurisprudence, "the last refuge of legal consciousness, ${ }^{105}$ from those such a legal positivists who wished to downplay or even sever the importance of jurisprudence to law. ${ }^{106}$ Similarly, after the war, Schmitt claimed that he was the 'last, conscious advocate of the jus publicum Euroaeum and, in an existential sense, I am its last teacher and researcher, ${ }^{107}$ implying that he saw himself as both a custodian and protector of European law and jurisprudence.

\footnotetext{
97 Schmitt, above n 8.

98 George Schwab, 'Introduction' in Schmitt, above n 91.

99 Schmitt, above 91, 14.

100 Ibid.

101 Schmitt, above n 56.

102 Mussawir, above 46, 134.

103 Ibid 133.

104 Ibid 57-58.

105 Ibid 64.

106 Ibid 45.

107 Andreas Fischer-Lescano, 'Social Networks and Individual Misdemeanors, Epistemological Questions and Normative Orientations’ (2006) 7 German Law Journal 127, 127.
} 
The theme of belonging to and protecting a great German intellectual tradition binds the work of these three scholars. Furtwängler saw himself as being deeply embedded in German culture. Writing in 1943, Furtwängler states that 'I am-in Germany and abroad - a German artist, that is, a representative of the Germany that manifests itself in German music. ${ }^{, 108}$ Furtwängler wished to protect music from not only those who wished to sever the organic link between it and the people, but also from Nazisim. As early as 1933 Furtwängler told Friedelind Wagner (granddaughter of the composer Richard Wagner and the only member of the Wagner family to leave Germany in protest of the rise of Nazism) that 'I feel it is my duty to stick it out here and save whatever can be saved artistically at a time when the country is headed for ruin and destruction. ${ }^{109}$ Similarly, in his closing remarks at his post-war denazification trial (he was unanimously acquitted of all charges) he stated that

I knew Germany was in a terrible crisis; I felt responsible for German music, and it was my task to survive this crisis, as much as I could. The concern that my art was misused for propaganda had to yield to the greater concern that German music be preserved, that music be given to the German people by its own musicians. These people, the compatriots of Bach and Beethoven, of Mozart and Schubert, still had to go on living under the control of a regime obsessed with total war. No one who did not live here himself in those days can possibly judge what it was like. Does Thomas Mann [who was critical of Furtwängler's actions] really believe that in 'the Germany of Himmler' one should not be permitted to play Beethoven? Could he not realize that people never needed more, never yearned more to hear Beethoven and his message of freedom and human love, than precisely these Germans, who had to live under Himmler's terror? I do not regret having stayed with them. ${ }^{110}$

It might seem to us rather naïve to attribute such power to music. Fred Prieberg in his generally sympathetic book Trial of Strength: Wilhelm Furtwängler and the Third Reich ${ }^{11}$ concludes that Furtwängler's 'naïve, clumsy semantic interpretation of history was-like all his notes - never thought through' ${ }^{112}$ and that

[a]rt, and especially music, cannot in itself be held up as a moral absolute; it is now taken for granted that every state will use art for its own ends, regardless of who happens to be in power... To attribute anything else to music is an ideology and illusion. This was why Furtwängler had to create a protective mythology between himself and the threat of such 'devaluation' if he was to spare himself from facing bitter reality... This means no more and no less than that he sacrificed himself to his own fiction. ${ }^{113}$

\footnotetext{
${ }^{108}$ Furtwängler, above n 9, 145.

109 Friedelind Wagner, 'Nazis or Non-Nazis? Is our “Screening” a Success?' (15 March 1946) 3128 Musical Courier 7, 7.

110 Ardoin, n 2, 59.

111 Fred Prieberg, Trial of Strength: Wilhelm Furtwängler and the Third Reich (Christopher Dolan trans, Quartet, 1991) [trans of: Kraftprobe: Wilhelm Furtwängler im Dritten Reich (first published 1986)].

112 Ibid 331.

113 Ibid.
} 
Perhaps though the best way to judge Furtwängler is to not impose our own sensibilities and judgements on what art is from the outside but to attempt to place ourselves internally into his perspective. As John Ardoin writes, 'to understand fully Furtwängler and his actions, one has to remember that his entire being was bound up with a profound sense of German history, art and culture, and it was motivated by a sense of duty and moral responsibility. ${ }^{, 14}$

Analysing Furtwängler's written philosophy of music alongside recordings of him conducting reveals a deep paradox in his work. On the one hand he was deeply committed to German intellectual tradition generally, decrying those who wished to dismantle the system of tonality and in doing so positioning himself as somewhat of a cultural conservative, and yet he was radically inventive when protecting music from Nazism. What were Furtwängler's radically inventive ways to protect German music from the Nazis? To answer this question we must turn away from Furtwängler's written philosophy of music and instead focus our attention to his actual music making.

\section{4 'Interpreter as Sovereign'-Carl Schmitt's idea of Sovereignty and Furtwängler's Wartime Performance of Beethoven's Ninth Symphony}

On one level a conductor is analogous to that of a judge. As Furtwängler expresses, 'music is for ever dependent on interpreters. ${ }^{115}$ This maxim is also true for law, specifically the role of the judge. Both examine a text which is often written by someone else (the score of a symphony, the constitution of a state) and are required to interpret it. In both law and music there is debate on how each ought to be interpreted, for example between those who advocate for a strict 'originalist' or textual interpretation of the music/law compared to those who see the text as a starting point in order to uncover the 'spirit' of what they are examining. ${ }^{116}$ As interesting as this debate is, it is not my intention to engage in it by suggesting that one form of interpretation in either law or music ought to be preferred and so on. Rather, I want to examine how interpreters in music are able to exhibit aspects of sovereign power by analysing Furtwängler's music making through the lens of Carl Schmitt's idea of sovereignty.

Furtwängler saw himself as a proud member of German cultural and intellectual life, a tradition which included not only great German musicians but also jurists. He spoke out against those who he saw as being detrimental to musical life, namely those who he saw as severing the links between music making and the community. There was also one other threat to music which Furtwängler recognised, namely that of the Nazi regime. As early as 1933 Furtwängler exclaimed that 'I feel it is my duty to stick it out here and save whatever can be saved artistically at a time when the

\footnotetext{
114 Ardoin, above n 2, 47-48.

115 Furtwängler, above n 62, 10.

116 Richard Posner, 'Bork and Beethoven' (1990) 42 Stanford Law Review 1365; Thomas, above n 16, 207-221.
} 
country is headed for ruin and destruction. ${ }^{117}$ The Nazis wished to claim sovereign control over all Germany, including its music. How then, did Furtwängler as a guardian and custodian of music, protect music from the Nazi regime? To answer this question I will move away from analysing Furtwängler's writings on music and instead focus on his actual performances, in particular a performance given by Furtwängler of Beethoven's Symphony No. 9 in D minor op. 125 'Choral' given on 19 April 1942 in honour of Hitler's birthday, through the lens of Carl Schmitt's theory of sovereignty.

Schmitt's idea of sovereignty can be traced to his work Political Theology, first published in 1922. In it Schmitt argues that the sovereign is "he who decides on the exception, ${ }^{118}$ namely he decides when a state of exception should be declared in times of crisis and with it the suspension of the law to effectively deal with that crisis. For Schmitt,

the sovereign produces and guarantees the situation in its totality. He has the monopoly over this last decision. Therein resides the essence of the state's sovereignty, which much be juristically defined correctly, not as the monopoly to coerce or to rule, but as the monopoly to decide. ${ }^{119}$

For Schmitt, a sovereign by definition must has the ability to decide when to suspend the ordinary workings of the law in times of crisis in order to effectively deal with that crisis and in doing so protect the polity from that crisis. The sovereign has untrammelled discretion as to when the law ought to be suspended, as well as what it is able to do in order to protect the polity when the law is suspended. ${ }^{120}$ The ultimate aim in suspending the normal operation of the law is to appropriately protect the polity from a crisis. ${ }^{121}$

The fundamental argument in this section is that Furtwängler acts as a Schmittian sovereign and protects the message of Beethoven's Ninth Symphony - a message of hope, brotherly love, unity_by crafting a most intense and violent performance, and in doing so suspending the normal message of the symphony. This suspension of the normal message of the Ninth Symphony has the effect of prevent the message of the piece-namely love and humanity_from being associated with the Nazi regime. For Furtwängler, the ultimate foundation of not only the Ninth Symphony but of art generally was that of love. 'The artist is the man of love.' 122 'Art does not express a nation's hate, but its love. It portrays man when he is 'himself,' harmless, trusting, simple, proud, a member of a happy, all-embracing humanity., ${ }^{, 23}$ Furtwängler realised full well however that he was producing music in a climate where there was no love, but only hate, and the way he responded to this was to drain the music itself of all notions of love, humanity etc., so that these concepts

\footnotetext{
117 Wagner, above n 109.

118 Schmitt, above n 8, 5.

119 Ibid 13.

120 Ibid 5-7.

121 Ibid.

${ }^{122}$ Furtwängler, above n 62, 74.

${ }^{123}$ Ibid 57.
} 
would not be associated with the Nazi regime. By denying the music of its love in the short term, he ultimately protects it in the long run. In this sense, Furtwängler acted in a way that is analogous to that of a sovereign as defined by Schmitt, namely 'he who decides on the exception' ${ }^{124}$ to suspend the law in order to protect the polity in a time of crisis. Furtwängler broadly acts as what Schmitt describes as a commissarial dictator, a sovereign power that 'suspends the constitution in concreto in order to protect its concrete existence. ${ }^{125}$ A commissarial dictator suspends the law so that 'the law can be realised' at a later stage after the state of exception has subsided. ${ }^{126}$

Comparing this section to the previous one reveals deep paradoxes in Furtwängler's work. On the one hand, as evidenced in his written philosophy of music, he was committed to a great German tradition and attacks those who in the name of 'progress' wish to usurp this tradition, but on the other hand in order to protect that tradition from the Nazis his music making became radically inventive. Furtwängler's written philosophy of music gives the impression of him being politically aloof, declaring that 'music and politics have nothing to do with each other, ${ }^{127}$ and yet his music making during the Nazi era was itself deeply political. Finally, he suspends the law (in this case Beethoven's Ninth Symphony) in order to ultimately fulfil it.

Both Furtwängler and Schmitt are rather ambiguous figures with their relationship to the Nazi regime. Schmitt's critique of liberalism may be seen as laying the intellectual foundation and justification of the Nazi regime. ${ }^{128}$ On the other hand his work has been built upon by left wing scholars to critique modern notions of power. Giorgio Agamben uses Schmitt to comment and criticise the American Guantanamo bay detention centre. ${ }^{129}$ In a similar vein, while Furtwängler was not a member of the Nazi party, there is continual debate as to how much prestige he leant to the regime by staying in Germany. ${ }^{130}$ Reading Furtwängler jurisprudentially will add a new perspective to this debate. I will argue that Furtwängler, by having sovereign control over the music, was able to resist and even work against the Nazi regime, even in circumstances where there would be a strong prima facie argument that he was working for the regime, namely by conducting for Hitler's birthday concert.

To fully understand and appreciate how Furtwängler suspends the ordinary message of Beethoven's Ninth symphony it is important at this state to give an overview of the work and thus what its ordinary meaning is.

\footnotetext{
124 Schmitt, above n 8, 5 .

125 Giorgo Agamben, State of Exception (Kevin Attell trans, The University of Chicago Press, 2005) 33 [trans of: Stato di eccezione (first published 2003)].

126 Ibid 33.

127 Shirakawa, above n 6, 203.

128 Christoph Burchard, 'The Nuremberg Trial and its Impact on Germany' (2006) 4 Journal of International Criminal Justice 800, 800-829.

129 Agamben, above n 125; Federico Luisetti 'Carl Schmitt and Giorgio Agamben: From Biopolitics to Political Romanticism' (2011) 1 Journal of Philosophy of Life 49.

130 Shirakawa, above n 6, 364.
} 


\subsection{Overview of Beethoven's Ninth Symphony}

Ludwig van Beethoven's Symphony No. 9 in D minor op. 125 'Choral' is his final completed symphony, finishing the work in 1824 . The symphony is written in a traditional four movement structure and is scored for orchestra, choir and solo vocalists, making it the first symphony written by a major composer to include voices in what was then seen as a purely instrumental genre of music. ${ }^{131}$ There is no question as to the grandness of the place which this symphony occupies in Western music, perhaps being one of the greatest achievements of humanity itself. As Nicholas Cook writes,

The Ninth Symphony has become one of the great symbols of great unity. What other work could possibly have been chosen for a global concert in which choirs and orchestras in Montreal, Moscow, Geneva and San Francisco performed together, linked by satellite? This is our Beethoven and our Ninth Symphony - a Ninth Symphony that has been a hundred and seventy years in the making, and that is part of the cultural, intellectual and political history of those years. ${ }^{132}$

It is well-nigh impossible to say exactly what the ultimate message and meaning of Beethoven's Ninth Symphony is in an objective sense. To even attempt to canvas the myriad of ideological positions and opinions of what the Ninth Symphony stands for is far beyond the scope of this article. ${ }^{133}$ In addition, there is debate in the philosophy of music as to whether or not it is even possible to come to any totally 'objective' determination as to what any musical work represents (this assumes too that music can 'represent' anything in the first place, with some suggesting that music ought to be seen as a pure 'thing' or process in its own right and not reduced to a mere representation of anything else, ${ }^{134}$ this approach having some affinity with those legal positivists such as Kelsen who wished to create a 'pure' theory of law). This tangent, while deeply fascinating and worthy of study, is also far beyond the scope of this article. For the purposes of this article what is necessary is to look at how Furtwängler himself viewed the work, to put us in his shoes, in his frame of mind regarding this work, and in doing allowing us to see how he suspends his own conception of the work.

Furtwängler's idea and conception of the Ninth is in accordance with the standard commonplace view of the work, namely a work showcasing and celebrating Beethoven's ultimate belief in the goodness of humanity. In the finale the choir sings lines from Friedrich Schiller's 'Ode To Joy' (An die Freude). As the

\footnotetext{
131 Mark Evan Bonds, 'Symphony: II. The 19th century,' The New Grove Dictionary of Music and Musicians (Macmillan, 2nd ed, 2001) vol 24, 837.

132 Nicholas Cook, Beethoven: Symphony No. 9 (Cambridge University Press, 1993) ix-x.

133 For book-length discussions of this very issue see: Esteban Buch, Beethoven's Ninth: A Political History (Richard Miller trans, The University of Chicago Press, 2003) [trans of La Neuvième de Beethoven: Une Histoire Politique (first published 1999)]; and: Cook, above n 132; just to cite a few.

134 Carl Dahlhaus, The Idea of Absolute Music (Roger Lustig trans, The University of Chicago Press, 1989) [trans of: Die Idee der absoluten Musik (first published 1978)].
} 
Beethoven scholar Barry Cooper puts it, from Schiller's fairly lengthy poem Beethoven

selected the passages closes to his heart, such as 'Alle Menschen werden Brüder,' [All men shall become brothers], which embodies his love for all humanity, and 'Über Sternen muß er wohnen' [He must dwell beyond the stars], which reflects his deep devotion to an all-powerful and all-loving Deity who dwells beyond the created universe. ${ }^{135}$

The main theme of the finale 'possess[es] such universal appeal that even the musically uninitiated can sense the joy it conveys. ${ }^{136}$ Cooper notes that sketches for a possible Tenth Symphony do exist, however based on the musical content of these sketches 'even if Beethoven had completed his Tenth, it would surely not have overshadowed the all-embracing, cosmic grandeur of the Ninth, which forms a magnificent climax to his symphonic output.' ${ }^{137}$

Similar comments regarding the Ninth Symphony have been made by the Austrian conductor and composer Felix Weingartner, who writes that the work is a 'deep, intense heart-outpouring of one of the greatest men and masters who have ever lived, which penetrates all the fibres of our being and shakes us to our very depths. ${ }^{138}$ Furtwängler, in writing at least, seems to associate himself with this grand view of the Ninth Symphony. Writing in 1942 at the height of the horrors of World War II, he expressed the view that

The most beautiful moments in [Beethoven's] music speak of an innocence, a childlike purity, which, in spite of all their human qualities, have an otherworldly aura about them. No composer has ever understood more about the harmony of the spheres or the inner peace of the Godhead. And it was from him that the words of Schiller's Ode to Joy, 'Brothers, there must be a loving Father living above the starry filament!' received their true, living meaning, a meaning that lies far beyond the reach of words. In the soul of Beethoven the musician there lies something of the soul of an innocent child. ${ }^{139}$

A year later in 1943 Furtwängler writes that 'the message which Beethoven directed at mankind in his works, and particularly in the Ninth Symphony, the message of goodness, of trust, of unity before God, seems to me never to have been more necessary than it is today.' 140

It is clear then that the main thrust for Furtwängler of Beethoven's Ninth Symphony is a world of joy, peace, harmony, unity, innocence, faith in God and His love, as well as love for each other in a brotherly sense, values which are completely

\footnotetext{
135 Barry Cooper, 'Introduction' in Ludwig van Beethoven, Symphony No. 9 in D minor op. 125 (Jonathan Del Mar (ed), Bärenreiter Urtext, 1999) iii, iii.

136 Ibid iv.

137 Ibid v.

138 Felix Weingartner, Weingartner on Music \& Conducting: Three Essays by Felix Weingartner (Ernst Newman, Jessie Crosland, H M Schott trans, Dover, 1969) 178.

139 Furtwängler, above n 10, 39.

140 Furtwängler, above n 9, 145.
} 
at odds with the horrifying reality of Nazi Germany at the time. The irony of conducting this work at the height of the horrors perpetrated the Nazi regime would not have been lost on Furtwängler. For John Andoin, this 'blatant dichotomy' 141 would have been felt by Furtwängler. As he eloquently writes,

It is impossible to listen to the [1942] Ninth without an acute awareness of the political and historical events of the moment, both in terms of Germany and Furtwängler. One of the noblest utterances of the human spirit was being voiced in a country engaged in some of the most appalling atrocities to be committed in the twentieth century. Furtwängler felt this blatant dichotomy, and it was surely responsible for the cyclonic fury of the 1942 performance. It is drenched with torment, anger, and a sense of struggle that goes beyond [his previous] 1937 Ninth to a more frightening and exhausting expressive plane. ${ }^{142}$

While many have rightly commented on the fury and anger of the performance, this analysis of the performance can also be extended into a jurisprudential one, in particular with reference to Carl Schmitt's idea of the nature and function of sovereign power.

The Nazi regime attempted to have sovereign control over the whole of Germany which included musical life. It did this by encouraging performances of 'good German' composers such as Beethoven, Brahms and Bruckner, and prohibited performances of Jewish composers such as Mendelssohn. Music would often feature at important Nazi events, such as at Hitler's birthday concert of 19 April 1942 where Beethoven's Ninth Symphony was played by the Berlin Philharmonic Orchestra conducted by Furtwängler. Furthermore, the Nazi regime attempted to appropriate the music of German composers such as Beethoven and Bruckner and present them as being part of Nazi cultural tradition. ${ }^{143}$ It is on the battlefield of music however that they met the skill and indignation of Furtwängler who resisted this sovereign control over music by making himself become a figure of sovereign power. Furtwängler himself was quite reluctant to conduct on this occasion, ${ }^{144}$ having no sympathies for the Nazi regime. It was only a threatening phone call delivered by the Reich Minister of Propaganda Joseph Goebbels that Furtwängler reluctantly agreed to conduct the work. ${ }^{145}$ This performance of Beethoven's Ninth Symphony on this occasion in particular was a vehicle for the Nazi party to exhibit both the greatest German composer Beethoven and the greatest conductor Furtwängler, and to present them as being part of the great Nazi cultural tradition. It was a major propaganda event in where the radio announcer of the concert boasted that it was broadcast not only in Europe but 'to Africa, North America, Central and South

\footnotetext{
141 Ardoin, above n 2, 147.

142 Ibid.

143 For an example of the efforts that the Nazis put into appropriating the music of Bruckner for their own ends, see: Bryan Gilliam, 'The Annexation of Anton Bruckner: Nazi Revisionism and the Politics of Appropriation' (1994) 78 Musical Quarterly 584.

144 Prieberg, above n 111, 292.

145 Shirakawa, above n 6, 277.
} 
America, South and East Asia and Australia. ${ }^{146}$ In addition, video footage of the last few minutes of the finale also exist showing a concert hall draped with large swastika flags, ${ }^{147}$ this footage being beamed around the world with the aim of demonstrating the greatness of Nazi culture. ${ }^{148}$ Goebbels himself delivered a speech before the concert in where he wanted the concert to serve as a 'declaration of loyalty ${ }^{149}$ to the Führer. All listeners to this concert, either in the concert hall itself or on radio 'will simultaneously sense the gravity of this hour, in which lies also the happiness of being privileged witnesses and participants in this, the greatest historical epoch of our people. ${ }^{150} \mathrm{He}$ insisted that Furtwängler, Germany's greatest conductor, was to lead the performance in order to give the entire event a transcendent dimension and to galvanise support for a regime which at the time was suffering from major military setbacks in the war, in particular the disastrous Battle of Moscow of 1941. ${ }^{151}$

To fully understand and appreciate Furtwängler's interpretation of the symphony it is necessary to compare this performance to more standard, 'neutral' performances of the work given in circumstances much less hostile than what is described above, and thus convey a more traditional understanding of what the symphony represents. The two main conductors I will compare Furtwängler's 1942 performance with are Felix Weingartner and his performance with the Vienna Philharmonic Orchestra from $1935^{152}$ and Christopher Hogwood and his performance with The Academy of Ancient Music from 1989. ${ }^{153}$ I chose Weingartner as, despite being a rough contemporary to Furtwängler and coming broadly from the German musical tradition, both represent different music trends in German musical life. While Furtwängler belonged to the 'subjective' school of conductors who

\footnotetext{
${ }^{146}$ Ludwig van Beethoven: Symphony No. 9 in D minor op. 125 'Choral,' Erna Berger soprano, Gertrude Pitzinger mezzo-soprano, Helge Rosvaenge tenor, Rudolf Watzke bass, Bruno Kittel Choir, Berlin Philharmonic Orchestra, conducted by Wilhelm Furtwängler, Recorded 19 April 1942 (Archipel Compact Disc, Catalogue Number ARPCD 0270, 2011).

147 Great Conductors of The Third Reich: Art in the Service of Evil (Produced by Stefan Zucker, Bel Canto Society, n.d.) 40:49-45:28 http://www.belcantosociety.org/store/product_info.php?products_id= 312; https://www.youtube.com/watch?v=2itdv1aEpG4.

148 Prieberg, above n 111, 292.

149 Ibid.

150 Ibid.

151 Audrey Roncigli, Le cas Furtwängler: un chef d'orchestre sous le IIIe Reich (Imago, 2009) 75.

152 Ludwig van Beethoven: Symphony No. 9 in D minor op. 125 'Choral,' Eleven Viennese Dances ('Elf Wiener Tänze'), Luise Helletsgruber soprano, Rosette Anday mezzo-soprano, Goerg Maikl tenor, Richard Mayr bass, Vienna State Opera Choir, Vienna Philharmonic Orchestra, conducted by Felix Weingartner, Recorded 2-5 February 1935 (op. 125) and 7-8 October 1938 (Tänze), (Pearl Compact Disc, Catalogue Number GEMM CD 9407, 1990).

153 Ludwig van Beethoven: Symphony No. 9 in D minor op. 125, Arleen Augér soprano, Catherine Robbin mezzo-soprano, Anthony Rolfe Johnson tenor, Ggregory Reinhart bass, London Symphony Chorus, The Academy of Ancient Music, conducted by Christopher Hogwood, Recorded 1989 (L'OiseauLyre Compact Disc, Catalogue Number 425 517-2, 1989).
} 
favour more fluid tempi, expressive playing, and more concern with uncovering the 'spirit' of the music rather than playing the music strictly as written, ${ }^{154}$ Weingartner belonged to the 'objective' school of conductors who prefer more fixed, brisker tempi and a performance style characterised by a subdued classically refined manner of playing, and performing the music as written instead of taking excessive liberties with the score. ${ }^{155}$ Weingartner, much like Furtwängler, also left a substantial amount of written material on music, ${ }^{156}$ which can be used for analysis. In addition to Weingartner, I choose Hogwood's 1989 recording of the work as stylistically he is seen as being a 'Historically Informed Performance' (HIP) or 'authentic performance' conductor. In many ways HIP music making is a logical extension of the 'objective' school in which Weingartner belonged to, particularly with the shared notion of playing the music objectively. This style of music making is characterised by attempting to perform the piece of music as closely to the composers' original intentions, in other words to perform it in a way that correlates with what the composer expected to hear at the time of the premiere of the work. This involves utilising scholarship on the performance practices of the period when the piece was written, as well as the use of 'period instruments,' or instruments that either come from or closely replicate the instruments from that period. There is debate as to whether such a 'historically informed' performance is actually achievable or not, namely the difficulty in finding out with exact certainty the intentions of the composer or conflicting primary sources on the nature of performance practice at the time. ${ }^{157}$ For our present purposes it is unnecessary to go into the details of this debate, but to simply state that both Hogwood's as well as Weingartner's performances of the Symphony attempt to be much closer to Beethoven's original intentions than Furtwängler's. I also make comparisons to other conductors such as Arturo Toscanini and Sergiu Celibidache where necessary and relevant. Comparing Furtwängler's performance to that of other conductors helps to show the unique aspects of Furtwängler's interpretation of the music in this performance.

\subsection{Notes on the Recordings Used for Analysis}

Before giving a musical analysis of the performance, two points must be discussed. The first one pertains to a technical matter, namely the actual recording used for analysis. Many of Furtwängler's wartime performances were recorded by the Reichs-Rundfunk-Gesellschaft (Reich Broadcasting Corporation) using then-state of the art magnetic tapes manufactured by the German company AEG and boast a remarkably high fidelity sound for their age. ${ }^{158}$ One of these tape recordings includes a performance of Beethoven's Ninth Symphony given between 22 to 24 March 1942. Furtwängler conducted the Berlin Philharmonic Orchestra with Tilla

\footnotetext{
154 Ardoin, above n 2, 22.

155 Gunther Schuller, The Compleat Conductor (Oxford University Press, 1998) 101-102.

156 Weingartner, above n 138.

157 Peter Kivy, 'On The Historically Informed Performance' (2002) 42 British Journal of Aesthetics 128.

158 Shirakawa, above n 6, 434-435.
} 
Briem, soprano, Elisabeth Höngen, mezzo-soprano, Peter Anders, tenor and Rudolf Watzke, bass, along with the Bruno Kittel Choir. Similar musical forces were subsequently used for the 19 April 1942 concert celebrating Hitler's Birthday with the exception of Erna Berger, soprano, Gertrude Pitzinger, mezzo-soprano, and Helge Rosvaenge, tenor, replacing the previously mentioned singers. Unfortunately the April concert survives as an inferior Decelith acetate disc recording which was privately recorded off the radio at the time. The poor sound quality is compounded by the use of aggressive digital noise reduction on the Archipel CD release, ${ }^{159}$ rendering a somewhat 'metallic' sound in places. Both performances are musically substantially similar to each other (given less than a month apart), as such it is advisable to listen to the sonically superior March recording. Many remasterings of the March recording have been done; one particularly successful and relatively easy to obtain is by Andrew Rose of Pristine Audio ${ }^{160}$ which has a superior tonal balance compared to other remasters of this recording. Unless otherwise stated, the musical analysis that follows is based on this Pristine Audio release.

The second point is that while a recording of a musical performance captures the sound, it does not capture the entire event itself. As Walter Benjamin notes,

Even the most perfect reproduction of a work of art is lacking in one element: its presence in space and time, its unique existence at the place where it happens to be. This unique existence of the work of art determined the history to which it was subject throughout the time of its existence. ${ }^{161}$

Similarly, Sergiu Celibidache highlights that 'a recording [of a concert]... will never replace the real, live experience. ${ }^{162}$ A recording of a performance, while providing a snapshot, does not entirely transport us to the event. A listener of the recording does not share the full context that someone who was actually at the concert, rather listeners of the recording are 'ghosts' to the event. For Furtwängler, music was a communal event, a kind of give-and-take relationship with the orchestra and the audience, and this was lost in recordings. 'One has to say, in general, that the record is still but an imperfect substitute for the collective experience of the music in the concert hall. ${ }^{163}$ It is impossible then for listeners today to totally place themselves within the time and place of the performance and be part of the collective experience of the performance as it originally unfolded.

With these two caveats in mind, I will now attempt a jurisprudential analysis of this exceptional performance and show how Furtwängler refuses to allow the love and humanity of the Ninth Symphony to become associated the Nazi regime, and in

\footnotetext{
159 Beethoven, above n 146.

160 Ludwig van Beethoven: Symphony No. 9 in D minor op. 125 'Choral,' Tilla Briem soprano, Elisabeth Höngen mezzo-soprano, Peter Anders tenor, Rudolf Watzke bass, Bruno Kittel Choir, Berlin Philharmonic Orchestra, conducted by Wilhelm Furtwängler, Recorded 22-24 March 1942 (Pristine Audio Compact Disc, Catalogue Number PASC250, 2010) https:/www.pristineclassical.com/collections/ artist-wilhelm-furtwangler/products/pasc250.

161 Walter Benjamin, Illuminations: Essays and Reflections (Harry Zohn trans, Schocken, 1968) 220.

162 Beethoven, above n 21.

163 Elizabeth Furtwängler, About Wilhelm Furtwängler (Hanni Raillard trans, Wilhelm Furtwängler Society of America, 1993) 99.
} 
doing so refusing to make the work a political anthem/soundtrack of the regime. For sake of word length I have only focused on moments where Furtwängler's reworkings of the symphony are the most blatantly obvious; a proper musical analysis of this performance alone could in my view fill an entire book. Beethoven's Ninth Symphony is made up of a typical four movement symphonic structure. For sake of clarity I will analyse Furtwängler's performance of each movement in turn. References to bar numbers, metronome markings etc. are of the Bärenreiter Urtext edition of the score, edited by Jonathan Del Mar and published in $1999 .{ }^{164}$

\subsection{1st Movement-Allegro ma non troppo, un poco maestoso ${ }^{165}$}

Furtwängler's radical reworking of the symphony can be heard right from the beginning; it is immediately obvious that this is no ordinary performance of the symphony. Beethoven begins the first movement with an ambiguous tonality. While the symphony itself is in D minor, the hushed pianissimo ${ }^{166}$ opening (bars 1-16) suggests a tonality of A Major. The ambiguity is resolved in bar 17 onwards, which forcefully grounds the tonality in D minor by the use of fortissimo ${ }^{167}$ block chords. In any performance this is a moment of tension, but Furtwängler makes this moment sound downright terrifying. He conducts the D minor statement in a rather angry and intense way, but also rather majestically and defiantly. He achieves this majestic defiance by giving more weight on Beethoven's indication that the movement ought to be played maestoso ${ }^{168}$ rather than Allegro ${ }^{169}$ and by rejecting Beethoven's rather quick metronome marking of 88 crotchet beats per minute. in favour of a more fluid tempi that fluctuates between 50 to 80 crotchet beats per minute. ${ }^{170} \mathrm{He}$ also gives great weight to the $\mathrm{D}$ minor chords from bars 17 onwards, turning them into big boulders of sound. Compare this to Hogwood's rendering of this passage, which musically is far more brisk and sprightly.

One of the innovations that Beethoven's brings to the first movement is that it does not climax at the middle of the development section-as is the convention of a movement written in sonata form at the time ${ }^{171}$ _but rather at the recapitulation. Delaying the expectant point of the climax creates a rather exciting effect. For Furtwängler however, this point is not merely exciting but downright terrifying, with the tympani in particular expressing a primal force, a deep earthquake of sound. While sounding radical compared to other performances, Furtwängler

\footnotetext{
${ }^{164}$ Ludwig van Beethoven, Symphony No. 9 in D minor op. 125 'Choral' (Jonathan Del Mar (ed), Bärenreiter Urtext, 1999).

165 Fast but not too much so, and a bit majestically.

166 To be played very softly.

167 To be played very loudly.

168 To be played majestically.

169 To be played in a quick, lively manner.

170 Sami-Alexander Habra, Furtwängler conducts Beethoven's Ninth Symphony in 1942, 1951 and 1954 (Société Wilhelm Furtwängler, 2008) http://www.furtwangler.net/beethoven/lvb9-1en.html.

171 Christopher Murray (ed), Encyclopedia of the Romantic Era: 1760-1850 (Fitzroy Dearborn, 2004) vol 2, 1070.
} 
achieves this by largely remaining faithful to Beethoven's written score. Between bars 301 to 326 Beethoven marks the tympani to play fortissimo and from bars 327 to 336 to play forte. ${ }^{172}$ Furtwängler is largely respectful of Beethoven's dynamic marking by having the tympani beat a sustained loud tone. This is to be contrasted to Weingartner's interpretation of this passage. Weingartner suggests dynamic gradients for the tympani that are not given by Beethoven himself. For example he suggests a set of crescendos $^{173}$ and decrescendos ${ }^{174}$ at bars 302 to 303,306 to 307, 309 to 310, and a crescendo from mezzo forte ${ }^{175}$ to fortissimo in bars 313 to 314. ${ }^{176}$ In this case however it is Furtwängler who is the most faithful to the score by eschewing the gradients in dynamics by having a continuous fortissimo rumble. Furtwängler elevates the tympani to a primal force of nature, a deep earthquake shattering the music which could be analogous to the deep tensions shattering Europe at the time. Specific attention should be drawn to bars 325 to 327, where the already pounding tympani heaves to a shattering climax, representing an almost wild outburst of primal energy. Furtwängler at once fulfils Beethoven's intentions but at the same time goes beyond it.

Another passage of note in this movement occurs at bars 427 to 469. Again Furtwängler respects the basic architecture set down by Beethoven, namely beginning the passage at piano and climaxing at bar 453 at fortissimo. But it is what Furtwängler does within this architecture that is astounding. Furtwängler begins the piano passage sounding perversely calm, but builds in nervous energy especially from bar 440 onwards, climaxing in a wild torrent of sound at bar 453. Compared to Hogwood's, and indeed most other performances of this work, Furtwängler deeply exaggerates the differences between the piano beginning and the fortissimo climax, from perverse calm to wild hysteria in such a short space of music. This passage musically illustrates what Friedland Wagner described as Furtwängler's 'floundering., 177

He always seemed to be floundering and wavering all over the place. He was a man who was very unsure of himself in so many ways, anybody who tried to do business with him or tried to pin him down on any issue found it very hard for him to commit himself. ${ }^{178}$

With the coda (bars 513 to 547) Furtwängler seals this movement with the same mood as the beginning - a mysterious beginning that climaxes with shattering D minor chords.

\footnotetext{
172 To be played loudly.

173 Gradually becoming louder.

174 Gradually becoming softer.

175 To be played moderately loud.

176 Weingartner, above n 138, 189-193.

177 NPR, Hitler's Conductor, Weekend Edition Saturday, 18 October 2003 (Friedland Wagner) 5:12-5:21 http://www.npr.org/templates/story/story.php?storyId=1470638.

178 Ibid.
} 


\subsection{2nd Movement-Molto vivace-Presto ${ }^{179}$}

The form of this movement is a scherzo and trio ${ }^{180}$ in all but name (despite often being labelled as such, Beethoven himself did not refer to this movement as a scherzo and trio). Furtwängler manages to whip the scherzo up into an unrelenting and menacing March, almost sounding like a hard driven and fanatic 'Devil's Dance.' The most touching aspect of Furtwängler's interpretation of this movement however is the ending of the trio, bars 491 to 530, in where he adds a gradual ritardando ${ }^{181}$ not written in the score. This mimics the natural breathing and sighing of a human being. It may also be seen as Furtwängler's hesitation to go back to the demonic scherzo section again, instead longing for the peace and serenity of the trio.

\subsection{3rd Movement-Adagio molto e cantabile ${ }^{182}$}

Beethoven alters the standard symphonic structure by presenting the slow movement third instead of second, as was the custom at the time. This slow movement is inherently calm and heart-felt, but Furtwängler elevates this movement into a deeply spiritual event. He achieves this by again pushing the music to extremes. However, unlike in the preceding two movements and the finale where the music is pushed to a violent, almost diabolical nature, here he does the opposite, namely attempting to deeply intensify and exploit the inherent spirituality of the music. While the first, third and fourth movements all express the wartime anguish, the third movement is a kind of spiritual 'escape' of the horrors of the time, a deep meditation, a moment of respite from the horror.

One very noticeable way in which Furtwängler pushes the music into extremes is the sheer length of time it takes to perform the movement, which is clearly an outlier when compared to more conventional performances of this symphony. Both Weingartner ${ }^{183}$ and Toscanini (in his 1952 performance with the NBC Symphony Orchestra) ${ }^{184}$ perform this movement in $14 \mathrm{~min}$ and $51 \mathrm{~s}$ and $14 \mathrm{~min}$ and $21 \mathrm{~s}$ respectively. Hogwood, who more closely follows Beethoven's metronome indication of 60 crotchet beats per minute, manages to perform this movement in $10 \mathrm{~min}$ and $42 \mathrm{~s} .{ }^{185}$ Furtwängler however pulls the music into an almost hypnotic $19 \mathrm{~min}$ and $48 \mathrm{~s}$, more than 5 min longer than the norm and almost 10 min longer than if Beethoven's metronome markings were followed. Only Sergiu Celibidache, a pupil of Furtwängler, performs this movement with a timing that is comparable to 
Furtwängler (his 1989 performance with the Munich Philharmonic Orchestra clocks in at 17 min and $43 \mathrm{~s},{ }^{186}$ and even that is around $10 \%$ faster than Furtwängler's). The effect of playing the music so slowly is to create a deeply spiritual, heartfelt and even slightly hypnotic sensation in the listener. It is as if Furtwängler was desperate in his attempts to hold onto this movement and thus experience for as long as possible the spiritual respite it provides from the horrors of the time.

Within this overall architecture created by the exceptionally slow tempi, the music itself is played in a deeply spiritual manner. The strings for instance play with a deep-seated intensity and beauty that is hard to describe in words. The structure of the movement is of theme and variations, but listening to this performance each separate variation becomes part of a seamless, organic flow. The movement climaxes with a fanfare played twice by the French horns and trombones-first at the end of bar 120 to bar 123 and again at the end of bar 130 to bar 133 . While other performances have a tendency to have this fanfare 'blasted out' without regard to the previous musical material, here the fanfare arises organically from the musical landscape. It is as if Furtwängler resists this fanfare from shattering the spiritual atmosphere created in the music but instead interweaves it inside of it. Right after the second fanfare at bar 133 the 'cellos and double basses play in such a rich, sustained manner, almost sounding like a deep note played by an organist on the pedalboard at a church organ. This moment is overwhelming in its spiritual intensity. Beethoven ends the movement with tender B flat major chords played by the woodwinds and horns at bar 157. From bars 155 to the end Furtwängler adds in a gentle ritardando not marked in the score, and the final B flat major chord in bar 157 is sustained by a fermata, ${ }^{187}$ again not marked in the score. Much like the added ritardando at the end of the trio section of the second movement, this ritardando and fermata act as if Furtwängler is trying for as long as possible to remain within the spiritual respite that the music provides.

Furtwängler's mode of escapism in this movement may be analysed through Francis Fukuyama's argument regarding Christianity. For Fukuyama, liberalism originates from and is in effect a kind of secularised form of Christianity as it attempts to realise the concept of freedom found in the afterlife by creating that freedom on earth.

The Christian God recognises all human beings universally, recognises their individual worth and dignity. ${ }^{188} \ldots$ The problem with Christianity, however, is that it remains just another slave ideology, that is, untrue in certain crucial respects. Christianity posits the realization of human freedom not here on earth but in the Kingdom of Heaven. ${ }^{189}$... For Hegel, then, completion of the historical process required only a secularization of Christianity, that is, a translation of the Christian idea of freedom into the here-and-now. ${ }^{190}$

\footnotetext{
186 Beethoven, above $\mathrm{n} 21$.

${ }^{187}$ Prolonging the note for longer than its written value.

${ }^{188}$ Francis Fukuyama, The End of History and The Last Man (Penguin Books, 1992) 197.

189 Ibid.

190 Ibid 198.
} 
In effect, liberalism and in extension laws based on it attempts to create heaven here in our present life on earth instead of waiting for this to occur in the afterlife. In this sense Furtwängler's whole interpretation of the third movement may be seen in this light. Much like the liberals who were impatient with Christianity's promise of freedom in the afterlife and thus wanted to create the conditions for freedom on earth, Furtwängler was impatient in that he did not want to wait for the Nazi regime to go but attempted to create an atmosphere of peace and tranquillity in the hereand-now. Unlike the liberals however, Furtwängler's escapism is just thatescapism. While Furtwängler clearly yearns for peace and freedom in the music, and achieves it momentarily, the conditions surrounding him remain the same-the Nazi state is still there, the war is still raging on. Furtwängler inadvertently gives musical weight to Carl Schmitt's argument regarding liberalism, namely that there exists 'absolutely no liberal politics, only a liberal critique of politics.' ${ }^{191}$ Furtwängler is only able to provide a liberal critique of politics through the music, but not a liberal solution to the situation itself. In this respect his attempt to create freedom is more in line with the Christian approach, a fantasy to be realised after the death of the regime.

\subsection{4th Movement-Presto ${ }^{192}$}

It is the finale in where Furtwängler's distortion and intensifying of the music reaches almost breaking point. For John Ardoin, the finale 'makes the greatest impact with its almost desperate appeal, as if Furtwängler were somehow attempting through the music to alter or reverse the events engulfing him. ${ }^{193}$ The finale begins with an opening fanfare which abruptly shatters the deep-seated spirituality of the adagio. Weingartner aptly describes it as being 'a wild disturbance of the peaceful, unworldly atmosphere which pervades the Adagio, ${ }^{194}$ 'a frightening fanfare (Schreckensfanfare)., ${ }^{195}$ Weingartner recommends this opening fanfare to be played immediately after the third movement, as 'the eminently dramatic character of this beginning never seemed to me to produce its genuine crushing effect when a long pause immediately followed the Adagio.' ${ }^{, 196}$ Furtwängler heeds this advice as the 19 April 1942 performance only has a four and a half second break between the adagio and the finale (by way of comparison the break between the first and second movements is $1 \mathrm{~min}$ and $17 \mathrm{~s}$ and the break between the second and third movements is $1 \mathrm{~min}$ and 30-s). This has the effect of devastatingly piercing and shattering the spirituality of the adagio, as if Furtwängler was returning 'back to earth' from that moment of spiritual escapism. While Weingartner writes that the fanfare is 'frightening,' under Furtwängler's direction

\footnotetext{
${ }_{191}$ Schmitt, above n $91,70$.

192 Fast.

193 Ardoin, above n 2, 147.

194 Weingartner, above n 138, 217.

195 Ibid.

${ }^{196}$ Ibid.
} 
the Schreckensfanfare sounds not only frightening but downright terrifying with shattering thunderbolt tympani strokes.

These moments of sheer terror continue as the finale progresses. At bars 321 to 330 the choir sings the phrase 'Und der Cherub steht vor Gott' three times. At the last repetition of the phrase Beethoven marks the final 'Gott' at bar 330 with a fermata. This is a moment of great intensity in any performance of this work, a deep reverence to the power and love of God. Furtwängler however turns this passage into a deep cry of despair by exaggerating the 'Gott' to sound not so much reverential but terrifying, holding the phrase as a kind of cry of despair, a primordial scream. This is done musically by lengthening the fermata to a much longer length than the norm and by the choir not singing but almost screaming out the word 'Gott.' At the same time, the tympani strikes a loud and firm forte with prominent trumpets, almost an apocalyptic call to God. As always, it is often difficult to put in words what is going on musically, and with this moment I find it near impossible. Words are an imperfect substitute for the actual listening of the music itself. I strongly suggest that you listen to this deeply terrifying moment yourself in order to understand it. This deeply exaggerated moment may be read in two ways. On the one hand it may be seen as Furtwängler's cry for help, a desperate plea and deep wish for God to come down and save Germany from the Nazis. However, it may also reflect Furtwängler's terrible fear in that when God does eventually come down, He may judge the German people and in extension its culture in a wholly negative light due to the actions of the Nazi regime, and may see fit to banish German culture. This moment shows Furtwängler's frightening fear that his aim at protecting German culture from the Nazis may possibly end up in vain.

The greatest single distortion in this performance however must lie with how Furtwängler strips the climax of the finale, namely the famous 'Ode to Joy' theme (bars 543 to 594), of any element of joy whatsoever. This melody has become so ubiquitous - from appearing in numerous television ads to becoming the anthem of the European Union, ${ }^{197}$ and symbolises unity, peace, and love. In this passage the choir sings phrases such as 'Freude, schöner Götterfunken' (Joy, beautiful spark of divinity) and 'Alle Menschen werden Brüder' (All men shall become brothers). Most conductors, including Furtwängler's post-war performances of this symphony (the 1951 Bayreuth Festival ${ }^{198}$ and 1954 Lucerne Festival $^{199}$ for example) emphasise the humanistic message being expressed in the music and the text. In this 1942 performance however this great moment is rendered with great irony. Furtwängler highlight the irony of the choir singing this humanistic text in an

\footnotetext{
197 Buch, above n 133, 233-234.

198 Ludwig van Beethoven: Symphony No. 9 in D minor op. 125 'Choral,' Elisabeth Schwarzkopf soprano, Elisabeth Höngen mezzo-soprano, Hans Hopf tenor, Otto Edelmann bass, Orchestra and Choir of the Bayreuth Festival, conducted by Wilhelm Furtwängler, Recorded 29 July 1951 (EMI Compact Disc, Catalogue Number 769801 2, 1984).

199 Ludwig van Beethoven: Symphony No. 9 in D minor op. 125 'Choral,' Elisabeth Schwarzkopf soprano, Elsa Cavelti mezzo-soprano, Ernst Häfliger tenor, Otto Edelmann bass, Lucerne Festival Choir, Philharmonia Orchestra, conducted by Wilhelm Furtwängler, Recorded 22 August 1954 (Audite SACD, Article Number 92.641, 2014) https:/www.audite.de/en/product/SACD/92641-wilhelm_furtwaengler_ conducts_beethovens_symphony_no_9.html.
} 
environment devoid of humanity by making them shout out these words in a tense, almost militaristic way. This is achieved musically by the choir singing these words in a highly articulated manner (tenuto ${ }^{200}$ with marcato $^{201}$ ), almost as if the choir is barking or shouting out the words, as well as conducting the passage at a faster tempi compared to the norm, giving the music an almost wild, hysterical character.

The sheer irony of people singing 'Alle Menschen werden Brüder' during the Nazi era was not only recognised by Furtwängler. Music played an important if now rather overlooked role in the Nazi death camps. ${ }^{202}$ A children's choir made up of inmates in the Auschwitz extermination camp practiced 'Ode to Joy' with the eventual aim of holding a concert. Tragically this never took place as on 7 March 1944 its members were murdered. ${ }^{203}$ One child however managed to survive. He recalls:

Sometimes I think of it as a magnificent demonstration of the spirit of universal values that can survive even the most inhumane deeds ever performed by the hand of man. That it was a protest and a resistance of the spirit in the face of crime and mass violence. But sometimes I have doubts about that interpretation. Perhaps the choice [to sing 'Ode to Joy'] was the expression of an extreme sarcasm, an almost satanic gesture. ${ }^{204}$

Similar horrific irony can be pointed to the motto of Auschwitz itself, the sign above the entrance reading 'Arbeit macht frei' (work makes you free).

This ironic moment in the performance is immediately followed by a moment of deep spirituality. Between bars 594 and 654 there is a dialogue between low pitched male voices and higher pitched female voices, with the male voices singing a line, the female voices replying to that line, and so on. Furtwängler renders this passage in a deep and genuinely felt manner. It represents a dialogue between man (represented by the male voices) and God (represented by the female voices). Furtwängler renders this passage in a similar way as the 'Vor Gott' moment, an attempt to bring God into the terrible situation around him.

This dialogue between man and God however ultimately fails to remedy the horrors surrounding Furtwängler, and this is expressed though the coda. The coda, bars 920 to 940 , seals the performance not with a vision of humanity but a vision of doom. Most conductors perform this passage with a festive grandeur. Weingartner writes that 'the magnificent orchestral tutti ${ }^{205}$ [of the coda] closes this stupendous work with one last shout of joy. ${ }^{206}$ Similar joy is expressed in Hogwood's performance in where the orchestral tutti is rendered with great clarity, with each instrument able to be heard separately and clearly. Under Furtwängler's baton however the coda becomes a crashing violent noise, a musical representation of the

\footnotetext{
200 Holding the time value of the note for its full length.

201 To be performed forcefully.

202 Buch, above n 197, 217; Simon Laks, Music of Another World (Northwestern University Press, 1989).

203 Buch, above n 197, 217.

204 Ibid 218.

205 All instruments playing together.

206 Weingartner, above n 138, 234.
} 
destruction that was being ravaged across Europe by the Nazis. This devastating effect is achieved by conducting these bars at twice the tempo that Beethoven marks in the score 88 semibreve beats per minute) and by exaggerating the cymbals over other instruments, and in turn destroying the clarity of the music. There is no shout of joy here, rather crashing shout of sheer devastation.

And thus ends this most extraordinary performance, not as a statement of peace and humanity as most conductors envision Beethoven's Ninth Symphony to be but of devastating crashing violence as if to symbolise the state of Europe at the time.

It is clear then that Furtwängler, by draining and denying Beethoven's Ninth Symphony of its customary humanity, was trying to protect it from the Nazis who wished to claim the work as their own and thus associate this humanity with themselves. It is somewhat interesting then that there are no contemporary accounts of the savagery from audience members who sat in the concert itself. Perhaps a very naïve interpretation of what Furtwängler was doing was to bring out the militaristic nature of the music and in effect to bring the music into the fold of Nazi militarism more generally, which possibly may have been the thought of some in the audience. This lack of contemporaneous reports may also be due to the fact that the listeners knew what was going on, but to express it openly would lead to almost certain reprisals from the authorities. There is however one clear indication of the effect that the concert had on the audience - on the Archipel CD right at the end of the last smashing chord of the coda the audience sit in silence for a full $10 \mathrm{~s}$ before they start to applaud. Usually for a work like this the applause is near-instantaneous at the end of the performance as to continue to joy and celebration set by the music. But here there was no joy, no celebration, to be continued on with applause.

Despite all this however, the Nazi authorities did their best to milk a propaganda victory from the concert, ${ }^{207}$ in particular Goebbels who wished to "projec[t] an image of a victorious and virile Third Reich. ${ }^{, 208}$ In the video snippet of the concert Goebbels can be seen clapping enthusiastically at the end, walking up to Furtwängler, and shaking his hand with approval. ${ }^{209}$ This video snippet, along with the live broadcast of the performance itself, had the propaganda effect of associating Furtwängler with the Nazis, and in effect appropriating his prestige onto the latter.

While Hitler himself did not attend the concert (in fact he never attended his birthday concerts given by the Berlin Philharmonic Orchestra) ${ }^{210}$ his assessment of Furtwängler's musicianship generally was glowing. Writing on 30 April 1942, 10 days after the concert, he states that, unlike Hans Knappertsbusch who while conducting 'indulged in such an extravaganza of gesture that it was better to avoid looking at him at all, ${ }^{211}$ Furtwängler is

\footnotetext{
207 Shirakawa, above n 6, 276-279.

208 Ibid 276.

209 Bel Canto Society, above n 147, 40:49-45:28.

210 The Reichsorchester: The Berliner Philharmoniker and the Third Reich (Written and Directed by Enrique Sánchez Lansch, Arthaus, 2007) 39:18-39:29 https://www.digitalconcerthall.com/en/film/108.

211 Adolf Hitler, Hitler's Secret Conversations: 1941-1944 (R H Stevens \& Norman Cameron trans, Farrar, Straus and Young, 1953) 364.
} 
the only conductor whose gestures do not appear ridiculous... His movements are inspired from the depths of his being. In spite of the meagre financial support he received, he succeeded in turning the Berlin Philharmonic Orchestra into an ensemble far superior to that of Vienna, and that is greatly to his credit. ${ }^{212}$

The aim of the Nazis, namely to have the concert serve as a propaganda boost for the regime, was successful. From this it may be deduced that while a sovereign may attempt to protect something by suspending either the law or the ordinary meaning of the text (in this case the humanistic message of the Ninth Symphony), this does not guarantee that such action will have the intended effect of actually protecting it. Having the sovereign 'suspend' the law is merely a tool that a sovereign can use in an attempt to protect, but the use of this tool does not ipso facto guarantee that it will actually work in protecting the polity or, in this case, the Ninth Symphony, from harm. Furtwängler's attempt at protecting Beethoven's Ninth Symphony from becoming a propaganda tool for the Nazis, in the short term at least, was not successful.

While in the short term the concert was a victory for the Nazi regime as they were able to use it as a propaganda tool, Furtwängler in the long run did in fact preserve the integrity of the Ninth Symphony by draining it of its customary humanity and in doing so denying its association with the Nazi regime. What was associated with the Nazi regime was a violent distortion of the Ninth symphony, and not its usual message of love and humanity. As Peter Gutmann so eloquently notes about his wartime performances in general;

Furtwängler's output of the time is of a wholly different dimension [compared to other conductors of the time], ranging far beyond the bounds of accepted classical tradition, distended by brutally twisted structures, outrageous tempos, jagged phrasing, bizarre balances and violent dynamics. This is simply not the expression of a cold-hearted Nazi. Rather, it clearly and irrefutably signifies a sensitive but deeply troubled man torn by inner conflict and soul-wrenching doubt, constantly on the verge of exploding with torment. Debate over Furtwängler's wartime politics may continue to swirl among academics, historians and social philosophers, but his artistry confers the ultimate proof of his humanity. There is no room for subtlety or doubt. No one sensitive to the interpretation of music can possibly mistake it. ${ }^{213}$

No one who is sensitive to the interpretation of music cannot escape what Furtwängler is doing musically to the symphony. It is potently clear that Furtwängler is trying his utmost to drain the humanity of the work. While denying the humanity of the Ninth Symphony during the war, Furtwängler's post-war performances of the symphony such as at the 1951 Bayreuth Festival $^{214}$ and the

\footnotetext{
212 Ibid.

213 Peter Gutmann, Wilhelm Furtwängler: Genius Forged in the Cauldron of War (Classical Notes, 1999-2002) http://www.classicalnotes.net/features/furtwangler.html.

214 Beethoven, above n 198.
} 
1954 Lucerne Festival ${ }^{215}$ overflow with sheer humanity, of feelings of love, hope and unity.

Furtwängler's at once demonstrates sovereign power in the mould of Schmitt and also highlights and accentuates deep paradoxes within the theory. Agamben notes these paradoxes when he comments that

Schmitt's theory of the state of exception proceeds by establishing within the body of the law a series of caesurae and divisions whose ends do not quite meet, but which, by means of their articulation and opposition, allow the machine of law to function. ${ }^{216}$

Schmitt's theory of sovereignty assumes that the entire legal system is suspended and that this suspension is noticeable and clear cut. However, Furtwängler, while he suspends the substance of the music in order to protect it, the music in a formal sense still exists. It is still Beethoven's Ninth that is performed at the concert, and not say Bruckner's Seventh Symphony, Brahms' Third Symphony, or any other work, or indeed silence. We are left with this curious situation in where the law is both entirely present and suspended at the same time. As Agamben writes, 'the suspension of the norm does not mean its abolition. ${ }^{217}$ But this goes further. Here both the norm and the suspension of the norm exist at the exact same time. Beethoven's Ninth both exists and is suspended at the exact same time. Reading Furtwängler jurisprudentially reveals even more of these caesurae, divisions, and paradoxes, both in Schmitt's work as well as Furtwängler's himself.

\section{General Conclusion of Article and Ideas for Further Law and Music Scholarship}

Wilhelm Furtwängler was not only a great conductor and composer of music but is also able to make an additional claim to fame-namely that of legal philosopher. Furtwängler's rich musical output, both in terms of his performances as well as writings, are wider than just music itself. They are capable of expressing and commenting on jurisprudential topics such as sovereignty and the nature of law itself.

Furtwängler saw himself as a member of a great German intellectual tradition, a tradition which included not only musicians but great German legal philosophers. He worked tirelessly to protect and preserve this great tradition. On the one hand he was deeply committed to that tradition, and resisted those who in the name of 'progress' attempted to usurp this tradition. On the other hand he attempted to protect this tradition from Nazism through radically inventive ways, namely by radically distorting the music so that the love inherent in the music would not be associated with the regime.

\footnotetext{
215 Beethoven, above n 199.

216 Agamben, above n 125, 35.

217 Agamben, ibid 23.
} 
Analysing Furtwängler's work shows that jurisprudence is not merely something that lawyers and academics do, but can be expressed in fields thought of being as 'non-legal' such as music. Music is not mere sound for entertainment value but can carry and express deep jurisprudential topics. Analysing music in such a way also illuminates and further extends our understanding of jurisprudence.

Obviously this article has merely scratched the surface of what can be achieved in law and music scholarship. While this article primarily sheds light on Furtwängler as a figure of jurisprudence, it leaves open the exciting possibility of analysing the work of other philosopher-musicians such as Sergiu Celibidache, Glenn Gould, Bruno Walter, John Cage, Pierre Boulez, just to name a few, through the lens of legal philosophy.

Acknowledgements This article is substantially based upon my Bachelor of Laws honours thesis. I would like to sincerely thank Dr Edward Mussawir, Senior Lecturer at the Griffith Law School, Griffith University, for his supervision and assistance during the writing of my thesis. Additional thanks must go to Professor Stephen Emmerson at the Queensland Conservatorium, Griffith University, for his helpful advice and suggestions regarding the music analysis sections. All errors or omissions are my own.

Open Access This article is distributed under the terms of the Creative Commons Attribution 4.0 International License (http://creativecommons.org/licenses/by/4.0/), which permits unrestricted use, distribution, and reproduction in any medium, provided you give appropriate credit to the original author(s) and the source, provide a link to the Creative Commons license, and indicate if changes were made.

\section{References}

\section{Books and Dissertations}

1. Agamben, Giorgo. 2005. State of exception (trans: Kevin Attell. The University of Chicago Press) [trans of: Stato di eccezione (first published 2003)].

2. Ardoin, John. 1994. The Furtwängler record. Portland: Amadeus Press.

3. Benjamin, Walter. 1968. Illuminations: Essays and reflections (trans: Harry Zohn). Schocken.

4. Bonds, Mark Evan. 2001. Symphony: II. The 19th century. In The new grove dictionary of music and musicians. 2nd ed., vol. 24 (New York: Macmillan).

5. Buch, Esteban. 2003. Beethoven's ninth: A political history (Richard Miller trans, The University of Chicago Press, 2003) [trans of La Neuvième de Beethoven: Une Histoire Politique (first published 1999)].

6. Clark, James Martin. 2005. Celebrating music: Wilhelm Furtwängler, Edwin Fischer, Wilhelm Kempff and the German romantic performance tradition, $\mathrm{PhD}$ Thesis, University of Connecticut.

7. Cook, Nicholas. 1993. Beethoven: Symphony No. 9. Cambridge: Cambridge University Press.

8. Dahlhaus, Carl. 1989. The idea of absolute music (Roger Lustig trans, The University of Chicago Press, 1989) [trans of: Die Idee der absoluten Musik (first published 1978)].

9. Freeman, Michael. 2014. Lloyd's introduction to jurisprudence, 9th ed. London: Sweet \& Maxwell.

10. Frisch, Walter. 1996. Brahms: The four symphonies. New York: Schirmer Books.

11. Fukuyama, Francis. 1992. The end of history and the last man. London: Penguin Books.

12. Furtwängler, Elizabeth. 1993. About Wilhelm Furtwängler. Hanni Raillard trans, Wilhelm Furtwängler Society of America.

13. Furtwängler, Wilhelm. 1953. Concerning music (L J Lawrence trans). London: Boosey \& Hawkes.

14. Furtwängler, Wilhelm. 1989. Notebooks 1924-1954 (Shaun Whiteside trans). London: Quartet Books. 
15. Furtwängler, Wilhelm. 1991. Furtwängler on music (trans: Ronald Taylor). London: Scolar Press.

16. Hitler, Adolf. 1953. Hitler's secret conversations: 1941-1944 (trans: R. H. Stevens \& Norman Cameron). New York: Farrar, Straus and Young.

17. Laks, Simon. 1989. Music of another world. Evanston: Northwestern University Press.

18. Levi, Erik. 1994. Music in the third Reich. New York: Macmillan.

19. MacNeil, William. 2007. Lex populi: The jurisprudence of popular culture. Palo Alto: Stanford University Press.

20. MacNeil, William. 2012. Novel judgments: Legal theory as fiction. New York: Routledge.

21. Manderson, Desmond. 2000. Songs without MUSIC: Aesthetic dimensions of law and justice. Berkeley: University of California Press.

22. Murray, Christopher (ed.). 2004. Encyclopedia of the romantic era: 1760-1850. Vol. 2. Chicago: Fitzroy Dearborn.

23. Mussawir, Edward. 2011. Jurisdiction in Deleuze: The expression and representation of law. New York: Routledge.

24. Parker, James E. 2015. Acoustic Jurisprudence: Listening to the trial of simon bikindi. Oxford: Oxford University Press.

25. Prieberg, Fred. 1986. Trial of strength: Wilhelm Furtwängler and the Third Reich (Christopher Dolan trans, Quartet, 1991) [trans of: Kraftprobe: Wilhelm Furtwängler im Dritten Reich (first published 1986)].

26. Ramshaw, Sara. 2013. Justice as improvisation: The law of the extempore. London: Routledge.

27. Reinmann, Mathias, and Joachim Zekoll (eds.). 2005. Introduction to German law. 2nd ed. Alphen aan den Rijn: Klewer Law International.

28. Roncigli, Audrey. 2009. Le cas Furtwängler: un chef d'orchestre sous le IIIe Reich. Thame: Imago.

29. Savigny, Frederick Charles von. 1831. Of the vocation of our age for legislation and jurisprudence (Abraham Hayward trans, Lawbook Exchange, 2011) [trans of: Vom Beruf unserer Zeit für Gesetzgebung und Rechtswissenschaft (2nd ed, 1831)].

30. Savigny, Friedrich Carl von. 1867. System of the modern roman law (William Holloway trans, J. Higginbotham, 1867) vol. 1.

31. Schmitt, Carl. 1985. The crisis of parliamentary democracy (Ellen Kennedy trans, MIT Press, 1985) [trans of: Die geistesgeschichtliche Lage des heutigen Parlamentarismus (first published 1923)].

32. Schmitt, Carl. 1932. The concept of the political: expanded edition (George Schwab trans, University of Chicago Press, 2007) [trans of: Der Begriff des Politischen (2nd ed, 1932)].

33. Schmitt, Carl. 1934. Political theology: Four chapters on the concept of sovereignty (George Schwab trans, University of Chicago Press, 2005) [trans of: Politische Theologie: Vier Kapitel zur Lehre von der Souveränität (2nd ed, 1934)].

34. Schönzeler, Hans-Hubert. 1990. Furtwängler. London: Duckworth.

35. Schuller, Gunther. 1998. The compleat conductor. Oxford: Oxford University Press.

36. Shirakawa, Sam. 1992. The Devil's music master: The controversial life and career of wilhelm furtwängler. Oxford: Oxford University Press.

37. Spengler, Oswald. 1932. The decline of the west (Charles Francis Atkinson trans, George Allen \& Unwin, 1932) [trans of: Der Untergang des Abendlandes (first published 1932)].

38. Thomas, James Burrows. 2006. Curious connections: Master musicians and the law. Brisbane: Supreme Court of Queensland Library.

39. Weingartner, Felix. 1969. Weingartner on music \& conducting: Three essays by Felix Weingartner (trans: Ernst Newman, Jessie Crosland and H. M. Schott). Grove: Dover.

\section{Journal Articles}

40. Burchard, Christoph. 2006. The nuremberg trial and its impact on Germany. Journal of International Criminal Justice 4: 800.

41. Fischer-Lescano, Andreas. 2006. Social networks and individual misdemeanors, epistemological questions and normative orientations. German Law Journal 7: 127.

42. Gilliam, Bryan. 1994. The annexation of Anton Bruckner: Nazi revisionism and the politics of appropriation. Musical Quarterly 78: 584.

43. Kivy, Peter. 2002. On the historically informed performance. British Journal of Aesthetics 42: 128. 
44. Luisetti, Federico. 2011. Carl schmitt and Giorgio agamben: From biopolitics to political romanticism. Journal of Philosophy of Life 1: 49.

45. Manderson, Desmond, and David Caudill. 1999. Modes of law: Musical and legal theory-An interdisciplinary workshop introduction. Cardozo Law Review 20: 1325.

46. Manderson, Desmond. 2014. Towards law and music: Sara Ramshaw, justice as improvisation: The law of the extempore Oxford: Routledge, 2013. Law and Critique 25: 311.

47. Mussawir, Edward. 2015. The Graves of law: The work of jurisprudence in Bachofen's Study of Tombs. Telos 171: 131.

48. Piška, Nick. 2013. Review: Edward Mussawir, jurisdiction in Deleuze, the expression and representation of law. Modern Law Review 76: 184.

49. Posner, Richard. 1990. Bork and Beethoven. Stanford Law Review 42: 1365.

50. Schmitt, Carl. 1990. The plight of European jurisprudence (G.L Ulmen trans). Telos 83: 35 [trans of: Die Lage der europäischen Rechtswissenschaft (2nd ed, 1973)].

51. Sykes, Robbie, and Kieran Tranter. 2015. 'You gotta roll/rule with it': Oasis and the concept of law. Griffith Law Review 24: 571.

52. Sykes, Robbie, and Kieran Tranter. 2017. A just (electric lady) land: Jimi Hendrix and John Rawls. Law \& Literature 29: 383.

53. Wagner, Friedelind. 1946. Nazis or Non-Nazis? is our "Screening" a success? Musical Courier 3128: 7.

\section{Audio Recordings, Videos, and Scores}

54. Beethoven, Ludwig van, Symphony No. 9 in D minor op. 125 (Jonathan Del Mar (ed), Bärenreiter Urtext, 1999).

55. Beethoven, Ludwig van: Symphony No. 9 in D minor op. 125 'Choral,' Eleven Viennese Dances ('Elf Wiener Tänze'), Luise Helletsgruber soprano, Rosette Anday mezzo-soprano, Goerg Maikl tenor, Richard Mayr bass, Vienna State Opera Choir, Vienna Philharmonic Orchestra, conducted by Felix Weingartner, Recorded 2-5 February 1935 (op. 125) and 7-8 October 1938 (Tänze), (Pearl Compact Disc, Catalogue Number GEMM CD 9407, 1990).

56. Beethoven, Ludwig van: Symphony No. 9 in D minor op. 125 'Choral,' Tilla Briem soprano, Elisabeth Höngen mezzo-soprano, Peter Anders tenor, Rudolf Watzke bass, Bruno Kittel Choir, Berlin Philharmonic Orchestra, conducted by Wilhelm Furtwängler, Recorded 22-24 March 1942 (Pristine Audio Compact Disc, Catalogue Number PASC250, 2010) https://www.pristineclassical. com/collections/artist-wilhelm-furtwangler/products/pasc250.

57. Beethoven, Ludwig van: Symphony No. 9 in D minor op. 125 'Choral,' Erna Berger soprano, Gertrude Pitzinger mezzo-soprano, Helge Rosvaenge tenor, Rudolf Watzke bass, Bruno Kittel Choir, Berlin Philharmonic Orchestra, conducted by Wilhelm Furtwängler, Recorded 19 April 1942 (Archipel Compact Disc, Catalogue Number ARPCD 0270, 2011).

58. Beethoven, Ludwig van: Symphony No. 9 in D minor op. 125 'Choral,' Elisabeth Schwarzkopf soprano, Elisabeth Höngen mezzo-soprano, Hans Hopf tenor, Otto Edelmann bass, Orchestra and Choir of the Bayreuth Festival, conducted by Wilhelm Furtwängler, Recorded 29 July 1951 (EMI Compact Disc, Catalogue Number 769801 2, 1984).

59. Beethoven, Ludwig van: Symphony No. 9 in D minor op. 125 'Choral,' Eileen Farrell soprano, Nell Merriman mezzo-soprano, Jan Peerce tenor, Norman Scott bass, Robert Shaw Chorale, NBC Symphony Orchestra, conducted by Arturo Toscanini, Recorded 31 March-1 April 1952 (RCA JVC Compact Disc, Catalogue Number JM-M24XR03, 2007).

60. Beethoven, Ludwig van: Symphony No. 9 in D minor op. 125 'Choral,' Elisabeth Schwarzkopf soprano, Elsa Cavelti mezzo-soprano, Ernst Häfliger tenor, Otto Edelmann bass, Lucerne Festival Choir, Philharmonia Orchestra, conducted by Wilhelm Furtwängler, Recorded 22 August 1954 (Audite SACD, Article Number 92.641, 2014). https://www.audite.de/en/product/SACD/92641wilhelm_furtwaengler_conducts_beethovens_symphony_no_9.html.

61. Beethoven, Ludwig van: Symphony No. 9 in D minor op. 125, Arleen Augér soprano, Catherine Robbin mezzo-soprano, Anthony Rolfe Johnson tenor, Ggregory Reinhart bass, London Symphony Chorus, The Academy of Ancient Music, conducted by Christopher Hogwood, Recorded 1989 (L'Oiseau-Lyre Compact Disc, Catalogue Number 425 517-2, 1989). 
62. Beethoven, Ludwig van: Symphony No. 9 in D minor op. 125 'Choral,' Helen Donath soprano, Doris Soffel mezzo-soprano, Siegfried Jerusalem tenor, Peter Lika bass, Munich Philharmonic Orchestra, conducted by Sergiu Celibidache, Recorded 17 March 1989 (EMI Compact Disc, Catalogue Number 7243556842 6, 1999).

63. Great Conductors of The Third Reich: Art in the Service of Evil (Produced by Stefan Zucker, Bel Canto Society, n.d.) 40:49-45:28. http://www.belcantosociety.org/store/product_info.php?products_ $\mathrm{id}=312$; https://www.youtube.com/watch?v=2itdv1aEpG4.

64. NPR. 2003. Hitler's conductor. Weekend Edition Saturday, 18 October 2003 (Friedland Wagner) 5:12-5:21. http://www.npr.org/templates/story/story.php?storyId=1470638.

65. The Reichsorchester: The Berliner Philharmoniker and the Third Reich (Written and Directed by Enrique Sánchez Lansch, Arthaus, 2007). https://www.digitalconcerthall.com/en/film/108.

\section{Websites}

66. Furtwaengler Institute Tokyo. http://www.kt.rim.or.jp/ otakesan/furt.htm.

67. Gutmann, Peter, Wilhelm Furtwängler: Genius forged in the cauldron of war (Classical Notes, 1999-2002). http://www.classicalnotes.net/features/furtwangler.html.

68. Habra, Sami-Alexander. 2008. Furtwängler conducts Beethoven's ninth symphony in 1942, 1951 and 1954. Société Wilhelm Furtwängler. http://www.furtwangler.net/beethoven/lvb9-1en.html.

69. Société Wilhelm Furtwängler. http://www.furtwangler.org/.

70. The Wilhelm Furtwängler Centre of Japan. http://furt-centre.com/english/eindex.htm.

\section{Cases}

71. Pfennig v The Queen. 1995. 182 CLR 461. 